\title{
Beyond the Fe-P-redox connection: preferential regeneration of phosphorus from organic matter as a key control on Baltic Sea nutrient cycles
}

\author{
T. Jilbert ${ }^{1}$, C. P. Slomp ${ }^{1}$, B. G. Gustafsson ${ }^{2}$, and W. Boer ${ }^{3}$ \\ ${ }^{1}$ Department of Earth Sciences (Geochemistry), Faculty of Geosciences, Utrecht University, P.O. Box 80.021, \\ 3508 TA Utrecht, The Netherlands \\ ${ }^{2}$ Baltic Nest Institute, Stockholm Resilience Centre, Stockholm University, 10691 Stockholm, Sweden \\ ${ }^{3}$ Royal Netherlands Institute for Sea Research (NIOZ), P.O. Box 59, Den Burg, Texel, The Netherlands
}

Received: 21 December 2010 - Published in Biogeosciences Discuss.: 21 January 2011

Revised: 15 April 2011 - Accepted: 16 May 2011 - Published: 28 June 2011

\begin{abstract}
Patterns of regeneration and burial of phosphorus $(\mathrm{P})$ in the Baltic Sea are strongly dependent on redox conditions. Redox varies spatially along water depth gradients and temporally in response to the seasonal cycle and multidecadal hydrographic variability. Alongside the welldocumented link between iron oxyhydroxide dissolution and release of $\mathrm{P}$ from Baltic Sea sediments, we show that preferential remineralization of $\mathrm{P}$ with respect to carbon $(\mathrm{C})$ and nitrogen $(\mathrm{N})$ during degradation of organic matter plays a key role in determining the surplus of bioavailable $\mathrm{P}$ in the water column. Preferential remineralization of $\mathrm{P}$ takes place both in the water column and upper sediments and its rate is shown to be redox-dependent, increasing as reducing conditions become more severe at greater water-depth in the deep basins. Existing Redfield-based biogeochemical models of the Baltic may therefore underestimate the imbalance between $\mathrm{N}$ and $\mathrm{P}$ availability for primary production, and hence the vulnerability of the Baltic to sustained eutrophication via the fixation of atmospheric N. However, burial of organic $\mathrm{P}$ is also shown to increase during multidecadal intervals of expanded hypoxia, due to higher net burial rates of organic matter around the margins of the deep basins. Such intervals may be characterized by basin-scale acceleration of all fluxes within the $\mathrm{P}$ cycle, including productivity, regeneration and burial, sustained by the relative accessibility of the water column P pool beneath a shallow halocline.
\end{abstract}

Correspondence to: $\mathrm{T}$. Jilbert

(t.jilbert@geo.uu.nl)

\section{Introduction}

Hypoxia has been intermittently present in the Baltic Sea throughout the Holocene (Zillen et al., 2008), but its severity and spatial extent have increased greatly over the past 100 years (Conley et al., 2009a; Fonselius and Valderrama, 2003; Jonsson et al., 1990). This has led to multiple ecological impacts, such as the disruption of benthic foodwebs (Karlson et al., 2005) and fish habitats (Cardinale and Modin, 1999). Rising anthropogenic nutrient loadings in the early 20th century are believed to have provided the initial trigger to the modern eutrophication of the Baltic, with the resulting increased biological oxygen demand forcing the exacerbation of hypoxia (Savchuk et al., 2008). However, both eutrophic conditions and hypoxia have persisted to the present day, despite a decline in fertilizer use in the catchment since the 1990s (Emeis et al., 2000). Natural feedbacks within the cycles of phosphorus $(\mathrm{P})$ and nitrogen $(\mathrm{N})$ in low-oxygen systems (Middelburg and Levin, 2009) likely play a key role in allowing the Baltic to self-sustain hypoxia. Regeneration of $\mathrm{P}$ as phosphate $\left(\mathrm{HPO}_{4}^{2-}\right)$ is known to be enhanced from sediments underlying hypoxic or anoxic bottom waters. Phosphate is released during the remineralization of organic matter, and the rate of $\mathrm{P}$ remineralization may accelerate relative to that of carbon and nitrogen during anaerobic degradation (Ingall et al., 1993). Additionally, the dissolution of P-bearing Fe-oxyhydroxides in surface sediments increases the rate of $\mathrm{P}$ regeneration during the transition into hypoxia or anoxia (Einsele, 1936; Mortimer, 1941, 1942). On the other hand, nitrification and denitrification rates may also vary as oxygen is depleted (Kemp et al., 1990). Basin-scale

Published by Copernicus Publications on behalf of the European Geosciences Union. 
biogeochemical modeling of the Baltic Proper through the last century shows the net result of altered anthropogenic nutrient loading and oxygen-dependent feedbacks to be an excess of phosphate in the modern water column (Savchuk et al., 2008). This situation stimulates the fixation of atmospheric $\mathrm{N}$ by cyanobacteria (Vahtera et al., 2007), maintaining high primary productivity in the basin. In turn, decay of sinking biomass maintains hypoxia in the bottom waters, providing the conditions for ongoing phosphate regeneration from the sediments.

Within the context of a generally eutrophied, hypoxic modern Baltic, the spatial distribution of hypoxia is controlled by the physical characteristics of the water column (Fonselius, 1981). In the Baltic Proper, a persistent stratification exists between surface waters of salinity 7-8 and bottom waters of salinity $11-13$, the latter generated by major inflows across the Danish Straits (Matthaus and Franck, 1992; Meier et al., 2006; Schinke and Matthaus, 1998). Vertical profiles of salinity and dissolved oxygen throughout the basin are strongly anti-correlated, with a mid-depth halocline marked by a steep decline in oxygen (Fonselius, 1981), across which turbulent diffusive exchange is limited (Gustafsson and Stigebrandt, 2007). The frequency of major saline inflows affects the spatial extent of hypoxia by determining the depth and gradient of the halocline. During stagnations (i.e. the multiannual periods between major inflows), the halocline may be eroded vertically, reducing the total area of bottom-water hypoxia. New inflows then reestablish a strong halocline, allowing bottom water hypoxia to spread (Gustafsson, 2000). Major inflows always occur during winter westerly storms across the Danish Straits, but their frequency has reduced dramatically from nearly annual in the early to mid-20th century to roughly decadal since 1983 (Schinke and Matthaus, 1998), with the most recent occurring in 2003. This change in frequency of major inflows is believed to result from the relative weakness of easterly winds in the early winter "preconditioning" phase during recent decades (Lass and Matthaus, 1996), and has led to highamplitude variability in the area of hypoxic bottom waters during this period (Conley et al., 2002). The size of the hypoxic area also displays a large seasonal fluctuation due to oxygen consumption after the spring-summer phytoplankton bloom (Conley et al., 2002).

Given the coupling between hypoxia and nutrient cycles, the strong physically-driven variability in bottom water hypoxia during the inflow-stagnation cycle may be expected to influence regeneration and burial of nutrients on the basinscale, and hence to influence nutrient budgets of the Baltic (Gustafsson and Stigebrandt, 2007; Savchuk and Wulff, 2009). In the case of $P$, it has been proposed that sediments in the Baltic Proper act as a net source of phosphate during expansion of the hypoxic area, as Fe-oxyhydroxides at the sediment surface are reductively dissolved in the absence of oxygen (Conley et al., 2002). Conversely, the opposite should be true as the hypoxic area contracts, namely that the sediments become a net sink for P. In accordance with this theory, the basin-scale modeling approach of Savchuk and Wulff (2009) considers a linear enhancement of P regeneration with expansion of the hypoxic area. Similarly, Gustafsson and Stigebrandt (2007) assume the uptake or release of P by sedimentary iron oxyhydroxides to account for any deviation in water column phosphate concentrations away from the value predicted by remineralization of organic matter in Redfield proportions. However, the behavior of phosphorus in Baltic Sea sediments has only recently begun to be studied in detail (Hille et al., 2005; Lukkari et al., 2009; Mort et al., 2010), and a large amount remains to be learned about the response of phosphorus regeneration, and burial, to spatial and temporal hydrographic variability. In particular, the respective roles of the iron oxyhydroxide-P (or "Fe-P") interaction, and preferential remineralization of $\mathrm{P}$ during anaerobic degradation of organic matter, are poorly constrained. Although some recent models, such as BALTSEM of the Baltic Nest Institute in Stockholm, include preferential remineralization of $\mathrm{P}$ from organic matter as a process (Oleg Savchuk, personal communication, 2011), a lack of comprehensive geochemical data hinders validation of its magnitude. The present study aims to address this issue. Firstly, we investigate the characteristics of $\mathrm{P}$ regeneration during the current stagnation using a broad network of sediment and porewater profiles throughout the Baltic Proper and the Gulf of Finland. We adopt a water-depth based approach, to investigate the contrasting behavior of sites along the redox gradient into the deep basins. Secondly, we investigate the response of $\mathrm{P}$ burial to the inflow-stagnation cycle by studying the accumulation rate of $\mathrm{P}$ in ${ }^{210} \mathrm{~Pb}$-dated sediment cores. The results allow a re-examination of existing theories about the relationship between hypoxia and the phosphorus cycle in the Baltic.

\section{Materials and methods}

\subsection{Onboard sampling and analyses}

A total of 17 sites in the Baltic Proper and Gulf of Finland, covering a range of water depths, were visited during the HYPER/COMBINE cruise of the R/V Aranda in May/June 2009 (Fig. 1). Water column salinity and dissolved oxygen profiles were measured using a CTD system, and additional bottom-water oxygen concentrations were measured by Winkler titration. A multicorer retrieving sub-cores of length $\leq 50 \mathrm{~cm}$ was deployed at each site. At 9 sites, a bottom water sample was taken from one sub-core using a $20 \mathrm{ml}$ plastic syringe, and transferred immediately to an anoxic glove box. The same sub-core was inserted into the glove box through an air-tight hole in the base and the remaining bottom water was removed. The sub-core was then sliced at a resolution of $0.5 \mathrm{~cm}(0-2 \mathrm{~cm}$ depth), $1 \mathrm{~cm}(2-10 \mathrm{~cm}$ depth $)$ and $2 \mathrm{~cm}(>10 \mathrm{~cm}$ depth). An aliquot of each wet sediment 


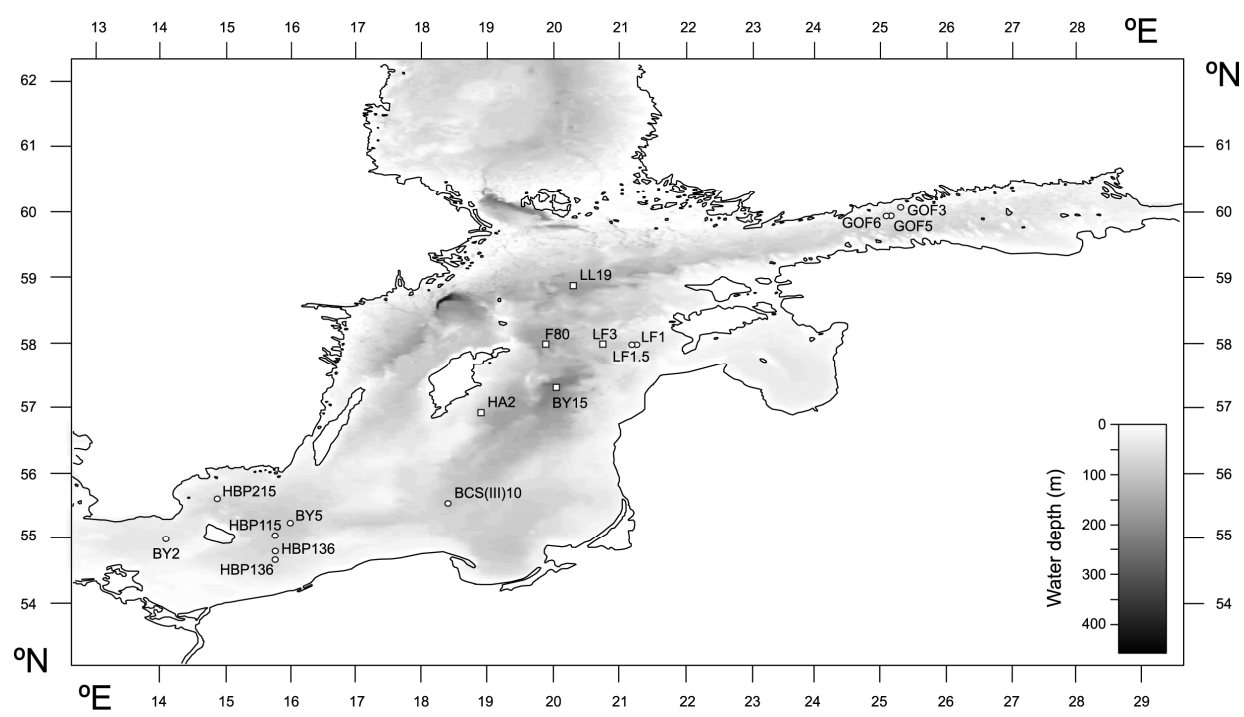

Fig. 1. Bathymetric map of the Baltic Proper, showing the locations of the coring sites used in this study. Circles represent Group 1 sites ( $\leq 90 \mathrm{~m}$ water depth), squares represent Group 2 sites ( $>90 \mathrm{~m}$ water depth). Bathymetric and coastline data are presented in equidistant cylindrical projection, taken from the General Bathymetric Chart of the Oceans (GEBCO) Digital Atlas (Intergovernmental Oceanographic Commission et al., 2003).

sample was transferred to a $50 \mathrm{ml}$ plastic centrifuge tube, which was capped, removed from the glove box and centrifuged at $2500 \mathrm{~g}$ for $10-30 \mathrm{~min}$. The centrifuge tubes were then returned to the glove box. The supernatant water from each sample, including the bottom water sample, was dispensed via a $20 \mathrm{ml}$ plastic syringe through a $0.45 \mu \mathrm{m}$ filter and collected in a $15 \mathrm{ml}$ plastic centrifuge tube. Subsamples were taken for analysis of dissolved phosphate and iron (acidified with $10 \mu \mathrm{l}$ of $37 \% \mathrm{HCl}$ per ml of subsample and stored at $5{ }^{\circ} \mathrm{C}$ ) and ammonium, nitrate and sulfate (stored at $-20^{\circ} \mathrm{C}$ ). The remainder of each wet sediment sample was transferred to a pre-weighed $15 \mathrm{ml}$ glass vial for solid-phase analyses. The vial was capped and stored in a nitrogen-filled airtight jar. At the remaining 8 sites, a bottom water sample was taken as above, and porewater samples were taken using rhizon samplers (Seeberg-Elverfeldt et al., 2005) from a sub-core pre-drilled with $3 \mathrm{~mm}$ diameter holes at $1 \mathrm{~cm}$ vertical spacing. The uppermost rhizon sample was taken from the first hole below the sediment water interface and was assumed to collect porewater from the upper $1 \mathrm{~cm}$ of sediment, centered on $0.5 \mathrm{~cm}$ depth. The rhizons were attached to $10 \mathrm{ml}$ plastic syringes, which were allowed to fill with porewater (for 10-30 min) and transferred to the glove box for subsampling as above. Site BY2 was also visited during a cruise with the R/V Skagerak in September 2007 and sampled for porewater and solid-phase parameters as per the above protocols, with porewater extraction by centrifugation (Mort et al., 2010).

\subsection{Laboratory analyses}

Phosphate, ammonium and nitrate in porewater samples were determined spectrophotometrically using an Autoanalyser. Sulfate was determined using a Dionex Ion Chromatograph. Iron and other elements in porewaters were analyzed by Perkin Elmer Optima 3000 Inductively Coupled PlasmaOptimal Emission Spectroscopy (ICP-OES; all iron was presumed to be present as $\mathrm{Fe}^{2+}$ ). Wet sediment samples from BY2, GOF3, GOF5, LF1, GOF6, LF1.5, LF3, LL19, F80 and BY15 were frozen within the airtight jars, then removed from the jars and freeze-dried to estimate water content. The dried sediment was transferred to an anoxic glove box and ground in an agate mortar. Aliquots of $0.5 \mathrm{~g}$ dried sediment were decalcified by shaking in excess $1 \mathrm{M} \mathrm{HCl}$, initially for $12 \mathrm{~h}$ and for a further $4 \mathrm{~h}$ after addition of new acid. Tests have shown that the amount of organic carbon hydrolyzed by this protocol is negligible (van Santvoort et al., 2002). The decalcified sediment was dried, ground in an agate mortar and analyzed by combustion for organic carbon $\left(\mathrm{C}_{\text {org }}\right)$ and total nitrogen $\left(\mathrm{N}_{\text {tot }}\right)$ using a Fisons NA 1500 NCS (precision and accuracy $<2 \%$ based on an atropine/acetanilide standard calibration and checked against internal laboratory standard sediments). The non-organic contribution to $\mathrm{N}_{\text {tot }}$ is assumed negligible in these sediments, hence $\mathrm{N}_{\text {tot }} \approx \mathrm{N}_{\text {org }}$. A second $0.1 \mathrm{~g}$ aliquot of dried sediment was dissolved in $2.5 \mathrm{ml} \mathrm{HF} \mathrm{(40 \% )}$ and $2.5 \mathrm{ml}$ of a $\mathrm{HClO}_{4} / \mathrm{HNO}_{3}$ mixture, in a closed Teflon bomb at $90^{\circ} \mathrm{C}$ for $12 \mathrm{~h}$. The acids were then evaporated at $190^{\circ} \mathrm{C}$ and the resulting gel was dissolved in $1 \mathrm{M} \mathrm{HNO}_{3}$, which was analyzed for selected elemental concentrations by ICP-OES (precision and accuracy $<5 \%$, based on calibration 
to standard solutions and checked against internal laboratory standard sediments). A third $0.1 \mathrm{~g}$ aliquot was subjected to the SEDEX sequential extraction procedure to determine the solid-phase partitioning of phosphorus (Ruttenberg, 1992). All $\mathrm{H}_{2} \mathrm{O}$ rinses were omitted from the original protocol (see Slomp et al., 1996), but three $\mathrm{MgCl}_{2}$ rinses were included. The full speciation was as follows: exchangeable-P (extracted by $1 \mathrm{M} \mathrm{MgCl}_{2}, \mathrm{pH} 8,0.5 \mathrm{~h}$ ), iron oxyhydroxide-bound $\mathrm{P}$ ("Fe-P", extracted by citrate-bicarbonate-dithionite (CDB), $\mathrm{pH} 7.5,8 \mathrm{~h}$, followed by $1 \mathrm{M} \mathrm{MgCl}_{2}, \mathrm{pH} 8,0.5 \mathrm{~h}$ ), authigenic $\mathrm{Ca}-\mathrm{P}$ (including carbonate fluorapatite, biogenic hydroxyapatite and $\mathrm{CaCO}_{3}$-bound $\mathrm{P}$, extracted by $\mathrm{Na}$-acetate buffer, $\mathrm{pH} 4,6 \mathrm{~h}$, followed by $1 \mathrm{M} \mathrm{MgCl}_{2}, \mathrm{pH} 8,0.5 \mathrm{~h}$ ), detrital Ca-P (extracted by $1 \mathrm{M} \mathrm{HCl}, 24 \mathrm{~h})$ and organic $\mathrm{P}\left(\mathrm{P}_{\text {org }}\right.$, after ashing at $550^{\circ} \mathrm{C}$ for $2 \mathrm{~h}$, extracted by $1 \mathrm{M} \mathrm{HCl}, 24 \mathrm{~h}$ ). The initial $1 \mathrm{M} \mathrm{MgCl}_{2}$ and CDB rinses were performed inside the anoxic glove box, to eliminate the potential conversion of authigenic Ca-P to $\mathrm{Fe}-\mathrm{P}$ due to pyrite oxidation upon oxygen exposure (Kraal et al., 2009). Dissolved phosphate in all rinses was analyzed colorimetrically (Strickland and Parsons, 1972) on a Shimadzu Spectrophotometer (precision and accuracy $<2 \%$, based on calibration to standard solutions and checked against internal laboratory standard sediments), with the exception of the CDB rinse, in which $\mathrm{P}$ and Fe were analyzed by ICP-OES. Only the $\mathrm{P}_{\text {org }}$ data (from all analyzed sites) and Fe-P data from BY2 (June and September) are presented in this paper. A fourth $0.1-0.5 \mathrm{~g}$ aliquot of dried sediment from sites LF1, LF1.5 and LF3 was reserved for ${ }^{210} \mathrm{~Pb}$ analysis. This was spiked with ${ }^{209} \mathrm{Po}$ and digested in $10 \mathrm{ml}$ concentrated $\mathrm{HCl}$ in a microwave oven for $3 \mathrm{~h} .2 \mathrm{ml} 3.5 \% \mathrm{HClO}_{4}$ was then added and the acids were removed by evaporation. The resulting precipitate was redissolved in $5 \mathrm{ml}$ concentrated $\mathrm{HCl}$ for $30 \mathrm{~min}$. Thereafter, $40 \mathrm{ml} 0.5 \mathrm{M} \mathrm{HCl}$ (with $12 \mathrm{gl}^{-1}$ boric acid), $4 \mathrm{ml} \mathrm{NH}_{4} \mathrm{OH}$ and $5 \mathrm{ml} 40 \mathrm{~g}^{-1}$ ascorbic acid (in $0.5 \mathrm{M} \mathrm{HCl}$ ) were added. Poisotopes were deposited by suspending silver disks in the solution, which was heated to $80^{\circ} \mathrm{C}$ for $4 \mathrm{~h}$ then left overnight at room temperature. The activity of ${ }^{210} \mathrm{Po}$ was measured by $\alpha$-spectrometry with Canberra Passivated Implanted Planar Silicon (PIPS) detectors, allowing ${ }^{210} \mathrm{~Pb}$ activity to be backcalculated. $1 \sigma$ counting uncertainty was on average $5 \%$.

\section{Results and discussion}

\subsection{Porewater profiles and regeneration fluxes}

A complete overview of the water column and porewater data from the 17 sites sampled in May/June 2009, and site BY2 from September 2007 (Mort et al., 2010), is presented in Fig. 2 (raw porewater data is presented in Table A1). The sites range in water-depth from $48 \mathrm{~m}$ (BY2) to $238 \mathrm{~m}$ (BY15). For simplicity and synergy with Mort et al. (2010), we categorize all sites of $<90 \mathrm{~m}$ depth as "Group 1 (oxicseasonally hypoxic)", whereas sites of $>90 \mathrm{~m}$ water depth are categorized as "Group 2 (semi-permanently hypoxicanoxic)". At the time of sampling in May/June 2009, all sites except BY2, LF1 and LF1.5 experienced bottom water oxygen concentrations below $2 \mathrm{ml} \mathrm{L}^{-1}$, hence were "hypoxic" as per the commonly adopted definition (Diaz and Rosenberg, 1995). The five Group 2 sites were anoxic, with hydrogen sulfide present in the water column (plotted in Fig. 2 as "negative oxygen" concentrations, as per Fonselius (1981)). The stratification control on water column oxygen concentration is clear from the inverse relationship between oxygen and salinity at all sites, although the depth and gradient of the halocline vary between and within sub-basins. Most sites display evidence for sulfate reduction in the porewaters, with complete removal of sulfate within the depth of the multicore at a number of sites. Porewater ammonium $\left(\mathrm{NH}_{4}^{+}\right)$profiles at all sites show an asymptotic increase with depth, typical of $\mathrm{NH}_{4}^{+}$release during organic matter remineralization in sediments undisturbed by bioturbation (Burdige, 2006). The flux of $\mathrm{NH}_{4}^{+}$across the sediment-water interface, calculated from the concentration gradient between the bottom water and uppermost porewater sample, therefore provides a minimum estimate of the rate of organic matter remineralization at each site. Although the true rate of remineralization at sites with oxygen penetration into the sediments may be greater, due to the oxidation of ammonium to nitrate in the uppermost sample, very low porewater nitrate concentrations at these sites (not shown) and the strongly asymptotic $\mathrm{NH}_{4}^{+}$profiles suggest this effect to be negligible. Hence, the relationship between the porewater profiles and fluxes of $\mathrm{NH}_{4}^{+}$, phosphate $\left(\mathrm{HPO}_{4}^{2-}\right)$ and iron (II) $\left(\mathrm{Fe}^{2+}\right)$ may justifiably be used to deconvolve regeneration of $\mathrm{HPO}_{4}^{2-}$ due to iron oxyhydroxide dissolution from regeneration due to remineralization of organic matter at the sites in this study.

Throughout both groups of sites, no clear trend is observed with water depth for absolute fluxes of $\mathrm{NH}_{4}^{+}$or $\mathrm{HPO}_{4}^{2-}$ (Fig. 2). This statement holds whether sites sampled with rhizons (marked "R" in Fig. 2, for which a greater degree of error is expected due to the difficulty in capturing the true concentration gradient across the sediment-water interface) are included or excluded. However, a marked depth-dependence is observed in the $\mathrm{NH}_{4}^{+} / \mathrm{HPO}_{4}^{2-}$ flux ratio (Fig. 3a). Most striking is the cluster of Group 1 sites recording values of $0-3$, while all Group 2 sites record values of 10-20. This distribution is explained by closer examination of the upper $10 \mathrm{~cm}$ of the porewater $\mathrm{NH}_{4}^{+}$and $\mathrm{HPO}_{4}^{2-}$ profiles at each site. Group 1 sites with $\mathrm{NH}_{4}^{+} / \mathrm{HPO}_{4}^{2-}$ flux ratios of 0-3 display a peak of porewater $\mathrm{HPO}_{4}^{2-}$ in the shallow subsurface which is not replicated in $\mathrm{NH}_{4}^{+}$(Figs. 2, 3b). This peak causes the diffusive $\mathrm{HPO}_{4}^{2-}$ flux to exceed the value predicted by organic matter remineralization alone, suppressing the $\mathrm{NH}_{4}^{+} / \mathrm{HPO}_{4}^{2-}$ flux ratio. Coincident peaks in $\mathrm{Fe}^{2+}$, which drive nonzero diffusive fluxes of $\mathrm{Fe}^{2+}$ (Figs. 2, 3c), provide evidence that dissolution of P-bearing iron oxyhydroxides close to the 


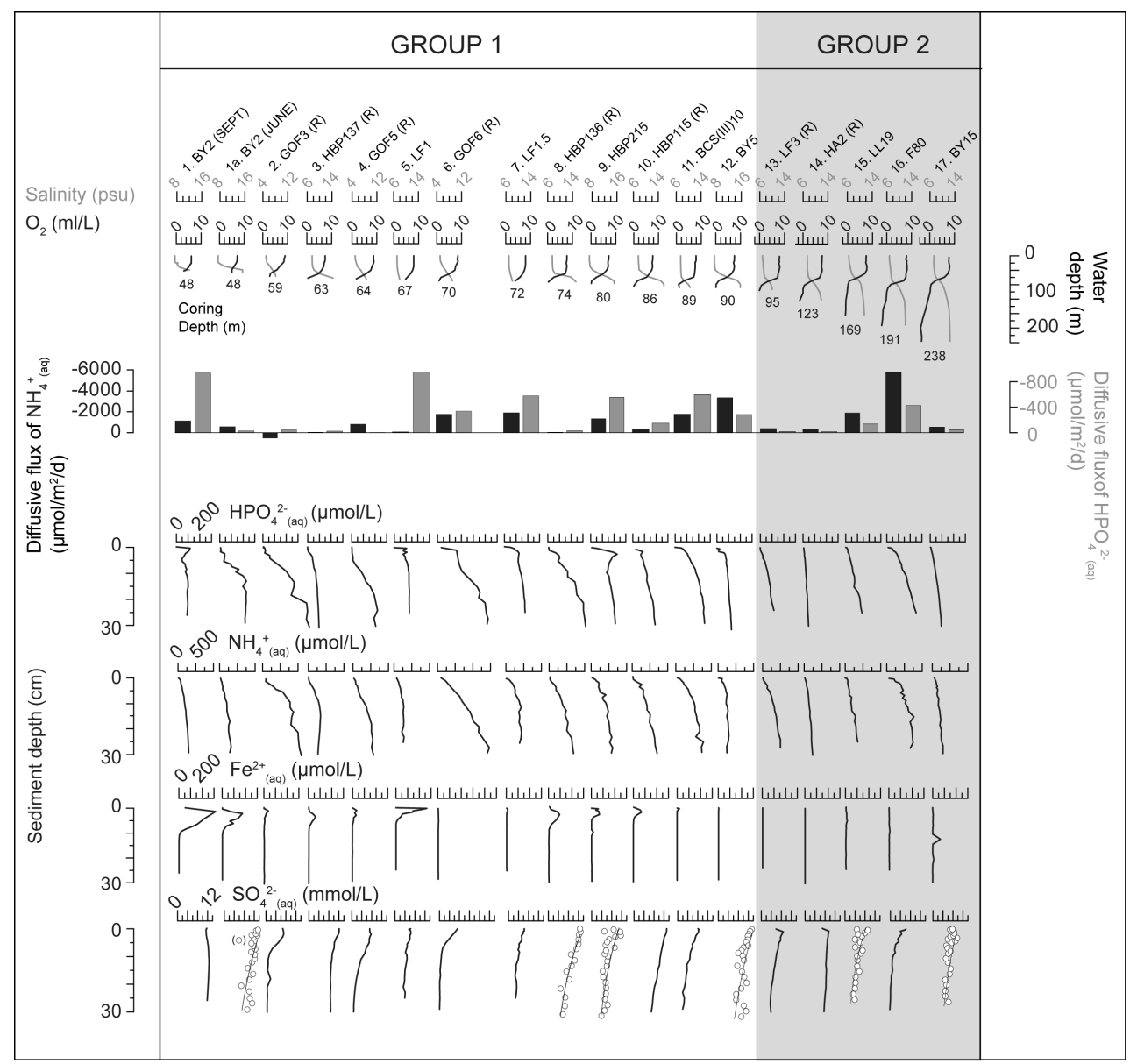

Fig. 2. Data array of sites used in this study, arranged by increasing water depth from left to right. Upper panel: Water column salinity and oxygen profiles. All profiles were measured during the HYPER/COMBINE cruise of the R/V Aranda in May/June 2009, except site 1. BY2 (Sept), for which profiles were measured during a cruise with the R/V Skagerak in September 2007 (Mort et al., 2010). Sub-zero oxygen concentrations are estimated from hydrogen sulfide concentrations using the ratio $1 \mathrm{~mol} \mathrm{H}_{2} \mathrm{~S}=2 \mathrm{~mol} \mathrm{\textrm {O } _ { 2 }}$ (see Fonselius, 1981). Middle panel: Diffusive fluxes of $\mathrm{NH}_{4}^{+}$and $\mathrm{HPO}_{4}^{-}$across the sediment-water interface, calculated from the concentration gradient between bottom water and the uppermost porewater sample $(0-0.5 \mathrm{~cm}$ depth for cores sliced for porewater extraction by centrifugation, $0-1 \mathrm{~cm}$ depth for cores sample with rhizons, indicated "R") using Fick's first law:

$F=-\frac{\varphi \cdot D}{\theta^{2}} \frac{\partial C}{\partial z}$

where $F=$ flux in $\mu \mathrm{mol} \mathrm{m}^{-2}$ day $^{-1}$, and minus sign indicates an efflux from the sediments, $D=$ ion-specific diffusion coefficient, corrected for temperature, taken from Boudreau (1997) and adjusted for salinity according to Van Cappellen and Wang (1995), $\phi=$ porosity and $\theta=$ tortuosity, defined as per Boudreau (1997):

$\theta^{2}=1-\ln \left(\varphi^{2}\right)$

Lower panel: Porewater profiles of $\mathrm{HPO}_{4}^{-}, \mathrm{NH}_{4}^{+}, \mathrm{Fe}^{2+}$ and $\mathrm{SO}_{4}^{2-}$. See text for details of sampling resolution and processing. $\mathrm{SO}_{4}^{2-}$ profiles for six sites are presented as logarithmic best-fit lines through raw data due to high scatter (data point in brackets for BY2 (June) not included in fit). All other profiles represent raw data only.

sediment-water interface was actively elevating the $\mathrm{HPO}_{4}^{2-}$ flux (relative to the expected flux from organic matter remineralization alone) at these sites at the time of sampling. Conversely, the lack of shallow-subsurface $\mathrm{HPO}_{4}^{2-}$ peaks at Group 2 sites suggests that iron oxyhydroxides are not presently involved in the $\mathrm{P}$ cycle at these water depths, and hence that organic matter remineralization alone dictates the rate of $\mathrm{HPO}_{4}^{2-}$ regeneration. Two Group 1 sites (BY2 and GOF5) record anomalously high $\mathrm{NH}_{4}^{+} / \mathrm{HPO}_{4}^{2-}$ flux ratios of 19 and 83, respectively (Fig. 3a). The porewater $\mathrm{HPO}_{4}^{2-}$ 
a

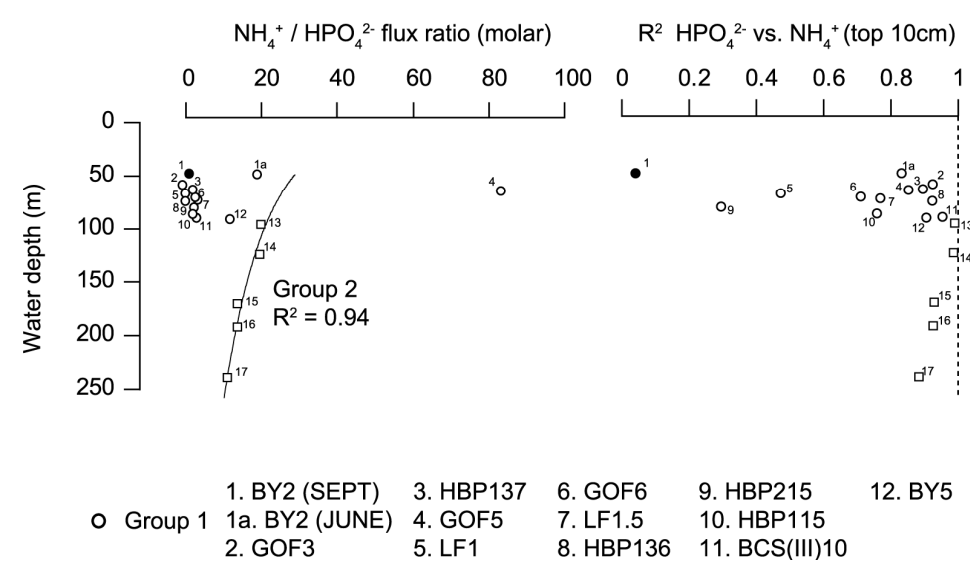

C

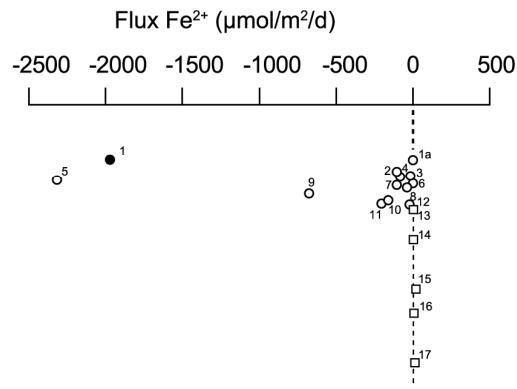

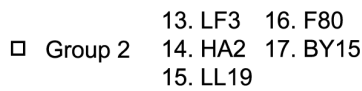

Fig. 3. (a) Ratio of diffusive fluxes of $\mathrm{NH}_{4}^{+} / \mathrm{HPO}_{4}^{-}$across the sediment-water interface vs. water depth for all sites. (b) Coefficient of determination $\left(R^{2}\right)$ for linear regression between porewater profiles of $\mathrm{NH}_{4}^{+}$and $\mathrm{HPO}_{4}^{-}$in the uppermost $10 \mathrm{~cm}$ of each core. Low $R^{2}$ indicates deviation of $\mathrm{HPO}_{4}^{-}$profile from asymptotic shape, caused by dissolution of Fe-P in surface sediments. Vertical dashed line represents perfect correlation $\left(R^{2}=1\right)$. (c) Diffusive flux of $\mathrm{Fe}^{2+}$ vs. water depth for all sites. Negative $=$ efflux.

a

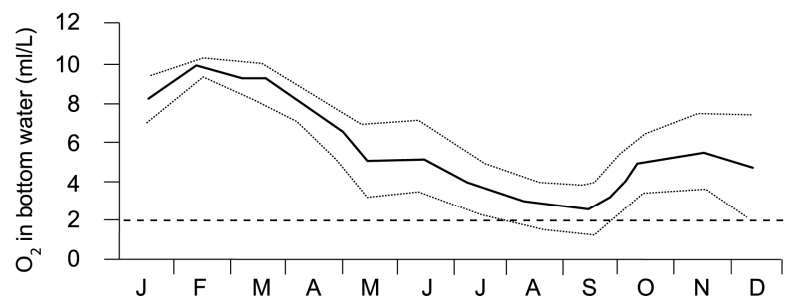

b

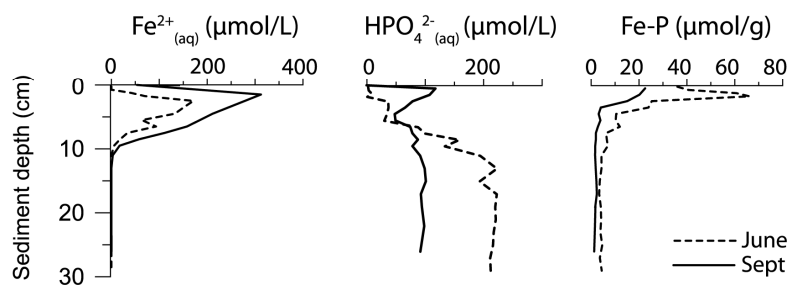

Fig. 4. (a) Seasonal variability in bottom water oxygen concentration at site BY2 in the Arkona Basin. Solid line represents mean values of 1995-2009, dotted lines the $20 \%$ and $80 \%$ quantiles. Data from Baltic Sea Environmental Database at Stockholm University, and Swedish Meteorological and Hydrological Institute. (b) Porewater profiles of $\mathrm{HPO}_{4}^{-}$and $\mathrm{Fe}^{2+}$, and solid phase profile of Fe-P at site BY2 in June and September sampling campaigns.

profiles at these sites display low values in the uppermost $\sim 5 \mathrm{~cm}$, and an increase below this depth (Fig. 2). Such profiles are characteristic of sediments with an intact layer of iron oxyhydroxides at the sediment-water interface (Slomp et al., 1996; Slomp et al., 1998) which adsorb $\mathrm{HPO}_{4}^{2-}$, thereby suppressing the diffusive flux of $\mathrm{HPO}_{4}^{2-}$ and elevating the $\mathrm{NH}_{4}^{+} / \mathrm{HPO}_{4}^{2-}$ flux ratio.
The total hypoxic area in the Baltic varies annually by some $10000 \mathrm{~km}^{2}$ (in a total of $20000-70000 \mathrm{~km}^{2}$, depending on the position in the inflow-stagnation cycle (Conley et al., 2002), due to the annual cycle of organic matter loading to the sediment-water interface (Stigebrandt, 1991). A substantial area of sediments above and within the halocline thus experiences major variability in redox conditions throughout the year, which may be expected to influence the interaction between iron oxyhydroxides and $\mathrm{HPO}_{4}^{2-}$ regeneration (Reed et al., 2011). Closer inspection of the data from site BY2, sampled both in June 2009 and September 2007, confirms the strong influence of seasonal redox variability on the $\mathrm{P}$ cycle. In the season of greatest oxygen stress (represented by September 2007), porewater peaks of $\mathrm{HPO}_{4}^{2-}$ and $\mathrm{Fe}^{2+}$ are present close to the sediment-water interface (Fig. 4), driving high diffusive fluxes of both species and suppressing the $\mathrm{NH}_{4}^{+} / \mathrm{HPO}_{4}^{2-}$ flux ratio (Figs. 2, 3). At this time, the concentration of Fe-P in the surface sediments is $\sim 20 \mu \mathrm{mol} \mathrm{g}^{-1}$ (Fig. 4). In contrast, during more oxic conditions (represented by June 2009) the subsurface porewater peaks of $\mathrm{HPO}_{4}^{2-}$ and $\mathrm{Fe}^{2+}$ are smaller and displaced downwards, enhancing the $\mathrm{NH}_{4}^{+} / \mathrm{HPO}_{4}^{2-}$ flux ratio, while the surface sediments contain up to $40-60 \mu \mathrm{mol} \mathrm{g}{ }^{-1} \mathrm{Fe}-\mathrm{P}$ (note: raw Fe-P data for BY2 in June 2009 are presented in Table B1). Furthermore, the mass of Fe-P in the upper $20 \mathrm{~cm}$ of a $1 \mathrm{~cm}^{2}$ sediment column in September 2007 was $21.4 \mu \mathrm{mol}$, compared with $49.1 \mu$ mol June 2009 (calculated from the profiles in Fig. 4 and dry bulk density data, not shown). These results confirm that a substantial fraction of the pool of $\mathrm{P}$ associated with iron oxyhydroxides in surface sediments at BY2 $\left(\sim 27.7 \mu \mathrm{mol} \mathrm{cm}{ }^{-2}\right)$ may be quickly regenerated to the water column during seasonal outbreaks of hypoxia, and 
conversely that $\mathrm{P}$ may be efficiently sequestered back to the sediments as oxygen conditions improve. It is noteworthy that seasonal outbreaks of even mildly "hypoxic" bottom water conditions, such as those observed at BY2 in September (Fig. 4), are able to trigger such a strong response in sedimentary Fe and $\mathrm{P}$ dynamics. Hence, although geochemical processes in bottom waters may not be expected to vary greatly across the biologically-defined "hypoxia" threshold of $2 \mathrm{ml} \mathrm{L}^{-1}$ dissolved oxygen, the vertical migration of redox zones within the underlying sediments leads to strong responses in sediment- and porewater-chemistry.

Due to the effects of seasonality, the data in Fig. 3 should be observed as a snapshot of conditions at the time of sampling. All sites currently experiencing seasonality in bottom water oxygen concentrations - hence all Group 1 sites - may reasonably be expected to show a variable flux of $\mathrm{HPO}_{4}^{2-}$ across the sediment-water interface throughout the year. The $\mathrm{HPO}_{4}^{2-}$ flux at such sites is strongly coupled to bottom water oxygen stress and the rate of iron oxyhydroxide dissolution in the sediments (Reed et al., 2011). The precise timing of the maximum $\mathrm{HPO}_{4}^{2-}$ flux may vary from site to site, due to the changing shape of the organic carbon loading curve in different regions of the Baltic (Stigebrandt, 1991), the ventilating action of small-scale inflows, and the water-depth dependent severity of oxygen depletion. A combination of these factors may account for the apparent offsets between the characteristics of BY2 and GOF5, versus the other Group 1 sites sampled in May/June 2009 (Fig. 3). In contrast, the Group 2 sites have experienced continuous hypoxia/anoxia throughout the year since early in the current stagnation, and the absence of iron oxyhydroxides in the surface sediments may be considered permanent within that time frame.

Closer inspection of the $\mathrm{NH}_{4}^{+} / \mathrm{HPO}_{4}^{2-}$ flux ratios at the five Group 2 sites (Fig. 3a) shows a trend of decreasing values from $\sim 20$ at the shallowest of the sites $(L F 3,95 \mathrm{~m})$ to $\sim 10$ at the deepest (BY15, 238 m). This observation suggests that the remineralization rate of $\mathrm{P}$ relative to $\mathrm{N}$ from organic matter in the surface sediments increases with water depth, supporting the concept of accelerated regeneration of $\mathrm{P}$ from sediments with increasing severity of anoxic conditions (eg., Algeo and Ingall, 2007; Ingall et al., 1993; Kraal et al., 2010; Slomp et al., 2002). The mechanism of this process remains uncertain, but may be related to redoxdependent variability in the storage or release of $\mathrm{P}$ by sedimentary micro-organisms during the breakdown of organic matter (see discussion in Ingall and Jahnke (1997)).

\subsection{Surface-sediment organic matter composition and relationship to regeneration fluxes}

Surface sediment organic C:N:P ratios allow the hypothesis of accelerated remineralization of $\mathrm{P}$ with increasing water depth to be tested. Hypothetically, if organic matter arriving at the sediment-water interface at all sites had a consistent $\mathrm{N}: \mathrm{P}$ ratio (Redfield or otherwise), surface sediment $\mathrm{N}_{\text {tot }}: \mathrm{P}_{\text {org }}$ should display the inverse trend to that of the $\mathrm{NH}_{4}^{+} / \mathrm{HPO}_{4}^{2-}$ flux ratio; namely an increase with water depth, reflecting the increase in preferential remineralization of $\mathrm{P}$. With some scatter, mean $\mathrm{N}_{\text {tot }}: \mathrm{P}_{\text {org }}$ in the top $2 \mathrm{~cm}$ of sediment at the ten sites selected for solid-phase analysis indeed shows an increase with water depth, from 32 at GOF3 to 57 at LL19 (Fig. 5a). The trend includes both Group 1 and Group 2 sites, suggesting that $\mathrm{NH}_{4}^{+} / \mathrm{HPO}_{4}^{2-}$ flux ratios at Group 1 sites would likely show the inverse relationship if the Fe$\mathrm{P}$ interaction was not active. A similar pattern is also observed in $\mathrm{C}_{\text {org }}: \mathrm{P}_{\text {org }}$, ranging from 328 at LF1 to 626 at LL19 (Fig. 5b), confirming that $\mathrm{P}$ is also preferentially remineralized relative to $\mathrm{C}$ with increasing oxygen stress (note that all raw $\mathrm{C}_{\text {org }}, \mathrm{P}_{\text {org }}$ and $\mathrm{N}_{\text {tot }}$ data are presented in Table B1). The shape of the $\mathrm{N}_{\text {tot }}: \mathrm{P}_{\text {org }}$ and $\mathrm{C}_{\text {org }}: \mathrm{P}_{\text {org }}$ vs. water depth relationships most likely reflects the change in water column oxygen with depth, with a higher rate of change per vertical meter in the Group 1 sites where oxygen decreases rapidly close to the halocline. Although reported as $\mathrm{C}_{\text {org }}$ : total $\mathrm{P}\left(\mathrm{P}_{\text {tot }}\right)$ and not explicitly stated by the authors, a depth-dependence in surface sediment $\mathrm{C}: \mathrm{P}$ ratios is also seen in the data of Emeis et al. (2000), with highest values at three stations of $>200 \mathrm{~m}$ depth in the Gotland Deep. Our maximum $\mathrm{C}_{\text {org }}: \mathrm{P}_{\text {org }}$ values of 500-650 indicate a 5-6 fold sedimentary enrichment of $\mathrm{C}$ relative to $\mathrm{P}$ from the Redfield ratio of $106: 1$, which is comparable to the values in Mediterranean sapropels (3001085, Kraal et al., 2010; Slomp et al., 2002), modern anoxic Black Sea sediments (mean value 558, Van Cappellen and Ingall, 1997) and Arabian Sea oxygen minimum zone sediments (400-800, Schenau and de Lange, 2001).

Interestingly, the convergence point of the exponential curves describing the $\mathrm{NH}_{4}^{+} / \mathrm{HPO}_{4}^{2-}$ flux ratio and surface sediment $\mathrm{N}_{\text {tot }}: \mathrm{P}_{\text {org }}$ is close to $\mathrm{N}: \mathrm{P}=27$ (Fig. 5a). One interpretation of this value is that it approximates the $\mathrm{N}_{\text {tot }}: \mathrm{P}_{\mathrm{org}}$ ratio of organic matter arriving at the sediment-water interface, and that during subsequent organic matter degradation, the $\mathrm{NH}_{4}^{+} / \mathrm{HPO}_{4}^{2-}$ flux ratio and $\mathrm{N}_{\text {tot }}: \mathrm{P}_{\text {org }}$ in the upper $2 \mathrm{~cm}$ of sediment then diverge to lower and higher values, respectively. The extent of the divergence is controlled by redox conditions in the sediments, with strongly reducing conditions causing the greatest offset. The initial value of 27 represents a two-fold enrichment relative to Redfield stoichiometry and appears high compared to the mean N:P values of material caught in sediment traps in the Gotland Deep ( $~ 9$ 11, Emeis et al., 2000; Struck et al., 2004). However, these studies report $\mathrm{N}_{\text {tot }}: \mathrm{P}_{\text {tot }}$, which may be suppressed by sinking or suspended non-organic $\mathrm{P}$ phases such as Fe-P and detritalP. Dellwig et al. (2010) show maxima in suspended $\mathrm{MnO}_{\mathrm{x}}-$ $\mathrm{FeOOH}-\mathrm{PO}_{4}$ in the vicinity of the redoxcline in the Gotland Deep, and in suspended $\mathrm{FeOOH}-\mathrm{PO}_{4}$ over a broad (at least $40 \mathrm{~m}$ ) depth range immediately below the redoxcline. Thus, both the $140 \mathrm{~m}$ and $230 \mathrm{~m}$ traps reported in Emeis et al. (2000) could potentially have collected non-organic $\mathrm{P}$ from these suspended phases, influencing the $\mathrm{N}_{\text {tot }}: \mathrm{P}_{\text {tot }}$ ratios. The convergence point in our sediment and diffusive 
a

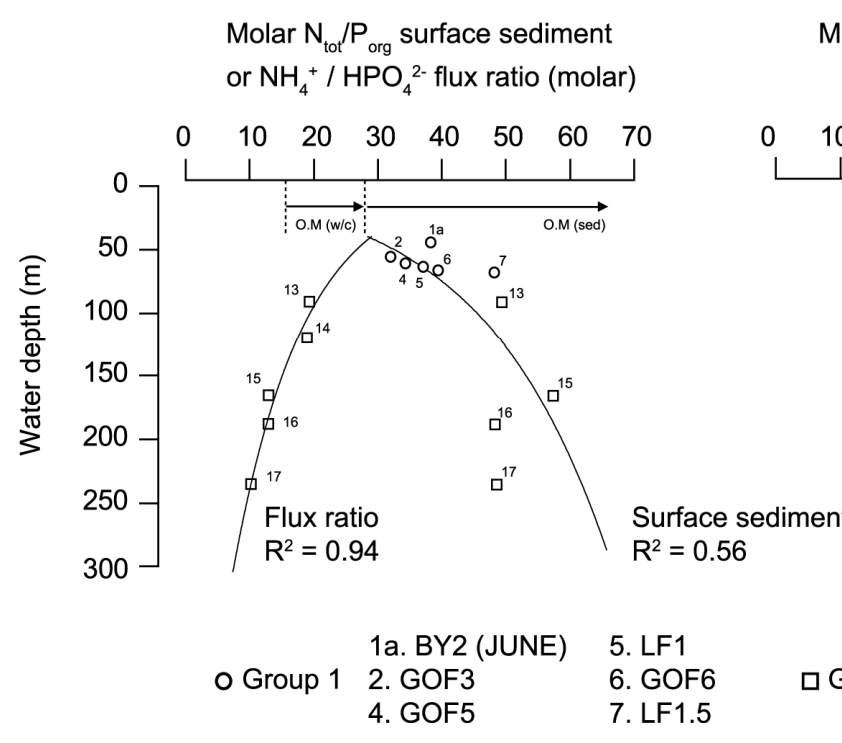

Molar $\mathrm{C}_{\text {org }} / \mathrm{P}_{\text {org }}$ surface sediment

100200300400500600700

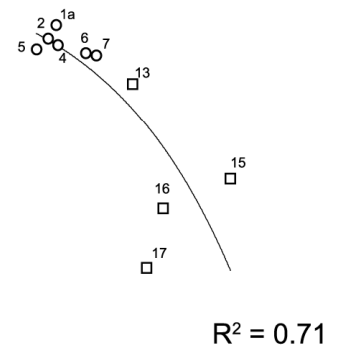

Fig. 5. (a) $\mathrm{NH}_{4}^{+} / \mathrm{HPO}_{4}^{-}$diffusive flux ratio at all Group 2 sites (left trendline and data), and sedimentary $\mathrm{N}_{\text {tot }} / \mathrm{P}_{\text {org }}$ ratio in the upper $2 \mathrm{~cm}$ of sediment at sites selected for solid phase analyses (from both Group 1 and 2, right trendline and data), plotted against water depth. Vertical dashed lines indicate Redfield ratio ( $\mathrm{N}: \mathrm{P}=16)$ and the intersection of the two trendlines $(\mathrm{N}: \mathrm{P}=27)$. Arrows represent inferred progression of $\mathrm{N}: \mathrm{P}$ ratio of organic matter during descent through the water column ("OM (w/c)"), from $16 \rightarrow 27$, and in the surface sediments (OM (sed)), from $27 \rightarrow$ a higher value, whose magnitude is determined by water depth-dependent preferential remineralization of P. (b) Sedimentary $\mathrm{C}_{\text {org }} / \mathrm{P}_{\text {org }}$ ratio in the upper $2 \mathrm{~cm}$ of sediment at the same sites plotted for $\mathrm{N}_{\text {tot }} / \mathrm{P}_{\text {org }}$ in (a).

flux data therefore provides a useful alternative estimate of the change in the N:P ratio of organic matter from its initial Redfield proportions during degradation in the water column, i.e. $16 \rightarrow 27$ (Fig. 5a). At Group 1 sites, this may surpass the magnitude of the change which subsequently occurs during degradation in the sediments $(27 \rightarrow 32-48)$, whereas for Group 2 sites the change after deposition $(27 \rightarrow 48-57)$ is greater than that in the water column. Lateral transport of organic material across the seafloor (Emeis et al., 2002; Jonsson et al., 1990) may allow older, partially degraded organic material to accumulate at deeper sites, potentially influencing the measured surface sediment $\mathrm{N}_{\text {tot }}: \mathrm{P}_{\text {org }}$. Specifically, organic material experiencing degradation during downslope transport - thus in relatively oxic conditions compared to those in the deep basin accumulation zone - would be expected to acquire depleted $\mathrm{N}_{\text {tot }}: \mathrm{P}_{\text {org }}$ and $\mathrm{C}_{\text {org }}: \mathrm{P}_{\text {org }}$ ratios, and therefore to dilute deep-basin surface sediment $\mathrm{N}_{\text {tot }}: \mathrm{P}_{\text {org }}$ towards lower values. This phenomenon could account for part of the scatter in the sediment data of Fig. 5a, most notably the relatively depleted $\mathrm{N}_{\text {tot }}: \mathrm{P}_{\text {org }}$ and $\mathrm{C}_{\text {org }}: \mathrm{P}_{\text {org }}$ ratios at $\mathrm{F} 80$ and BY15. However, the lack of such scatter in the $\mathrm{NH}_{4}^{+} / \mathrm{HPO}_{4}^{2-}$ flux ratio $\left(R^{2}=0.94\right.$ for all Group 2 sites $)$ suggests that the laterally transported material is refractory once accumulated in the deep basins and does not contribute significantly to remineralization at these depths.

\subsection{Implications of preferential $P$ remineralization for basin-scale DIP during inflow-stagnation cycles}

Due to preferential remineralization of P, Redfield-based modeling of organic matter breakdown in the Baltic may underestimate the magnitude of the direct remineralization flux to the total rate of $\mathrm{P}$ regeneration during stagnations, and hence the total pool of $\mathrm{P}$ in the water column. Simple budget calculations based on the modeled deep-basin carbon and phosphorus flows of Gustafsson and Stigebrandt (2007) support this claim (Table 1). The model of Gustafsson and Stigebrandt (2007) calculates a mean burial efficiency of $48 \%$ of all $\mathrm{C}_{\text {org }}$ passing through the $150 \mathrm{~m}$ water depth horizon in the Gotland Deep. Using this value, and measured deep-basin $\mathrm{C}_{\text {org }}$ and $\mathrm{P}_{\text {org }}$ accumulation rates (from this study, Hille, 2005 and Hille et al., 2005), it can be shown that preferential remineralization of $\mathrm{P}$ from the buried fraction $(48 \%)$ of the organic matter adds $0.13-0.29 \mathrm{~g} \mathrm{~m}^{2} \mathrm{yr}^{-1} \mathrm{P}$ to the $0.32-$ $0.39 \mathrm{~g} \mathrm{~m}^{2} \mathrm{yr}^{-1} \mathrm{P}$ released during complete remineralization of the other $52 \%$. This is of a similar order of magnitude to the mean value of $\mathrm{R}_{\mathrm{Fe}}$ - the "additional" amount of $\mathrm{P}$ required to balance observed water-column concentrations during five completely anoxic stagnations since 1965 in the Gotland Deep (Gustafsson and Stigebrandt, 2007). $\mathrm{R}_{\mathrm{Fe}}$ is assumed to represent the dissolution of sedimentary Fe-P, thus the non-zero values during completely anoxic stagnations are unexpected, since no iron oxyhydroxides should be present 
Table 1. Summary of carbon and phosphorus fluxes in deep basins of the Baltic.

\begin{tabular}{|c|c|c|c|c|c|c|c|c|c|}
\hline & & A & B & $\mathrm{C}$ & $\mathrm{D}$ & $\mathrm{E}$ & $\mathrm{F}$ & G & $\mathrm{H}$ \\
\hline Parameter & & $\begin{array}{l}\mathrm{C}_{\text {org }} \\
\text { accumulation } \\
\text { rate in } \\
\text { sediments }\end{array}$ & $\begin{array}{l}\text { Flux of } C_{\text {org }} \\
\text { through } \\
150 \mathrm{~m} \text { depth } \\
\text { horizon* }\end{array}$ & $\begin{array}{l}\text { Rate of } \\
\text { complete } \\
\text { remineral- } \\
\text { ization } \\
\text { of } \mathrm{C}_{\text {org }}\end{array}$ & $\begin{array}{l}\text { Rate of } \\
\text { complete } \\
\text { remineral- } \\
\text { ization } \\
\text { of } P_{\text {org }}\end{array}$ & $\begin{array}{l}\text { Remaining } \\
\mathrm{P}_{\text {org }} \\
\text { available } \\
\text { for burial }\end{array}$ & $\begin{array}{l}\mathrm{P}_{\text {org }} \\
\text { accumulation } \\
\text { rate in } \\
\text { sediments }\end{array}$ & $\begin{array}{l}\text { Preferential } \\
\text { remin. flux } \\
\text { of } \mathrm{HPO}_{4}^{2-} \\
\text { into water } \\
\text { column }\end{array}$ & $\begin{array}{l}\text { Mean excess } \\
\mathrm{HPO}_{4}^{2-} \text { flux } \\
\text { during } \\
\text { anoxic } \\
\text { stagnations* }\end{array}$ \\
\hline Calculation & & Measured & $2.07 \times \mathrm{A}$ & $\mathrm{B}-\mathrm{A}$ & $\begin{array}{l}\mathrm{C} / 41 \\
\left(\mathrm{~g} \mathrm{~m}^{-2} \mathrm{yr}^{-1}\right) \\
\mathrm{C} / 106 \\
\left(\mu \mathrm{mol} \mathrm{m}{ }^{-2} \mathrm{~d}^{-1}\right)\end{array}$ & $\begin{array}{l}\mathrm{A} / 41 \\
\left(\mathrm{~g} \mathrm{~m}^{-2} \mathrm{yr}^{-1}\right) \\
\mathrm{A} / 106 \\
\left(\mu \mathrm{mol} \mathrm{m}{ }^{-2} \mathrm{~d}^{-1}\right)\end{array}$ & Measured & $\mathrm{E}-\mathrm{F}$ & \\
\hline $\begin{array}{l}\text { Code (Gustafsson } \\
\text { and Stigebrandt, } \\
\text { 2007) }\end{array}$ & & $\left(\mathrm{F}_{\mathrm{SA}}\right)_{\mathrm{Corg}}$ & $\left(\mathrm{F}_{\mathrm{O}}\right)_{\mathrm{Corg}}$ & $\begin{array}{l}\left(\mathrm{R}_{\mathrm{O}}+\right. \\
\left.\mathrm{R}_{\mathrm{DEN}}\right) \text { Corg }\end{array}$ & & & & & $\mathrm{R}_{\mathrm{Fe}}$ \\
\hline \multicolumn{10}{|l|}{ Coring site (study) } \\
\hline & $\mathrm{g} \mathrm{m}^{-2} \mathrm{yr}^{-1}$ & & & & & & & & \\
\hline $\begin{array}{l}\text { F80, Fårö Deep, } \\
0-5 \mathrm{~cm} \text { of } \\
\text { sediment }= \\
2003 \text {-present } \\
\text { (this study) }\end{array}$ & & 12.2 & 25.2 & 13.0 & 0.32 & 0.30 & 0.17 & 0.13 & 0.30 \\
\hline \multicolumn{10}{|l|}{$\begin{array}{l}\text { in Gotland basin } \\
\text { (Hille } 2005 \text {; } \\
\text { Hille et al., 2005) }\end{array}$} \\
\hline & $\mu \mathrm{mol} \mathrm{m}{ }^{-2} \mathrm{~d}^{-1}$ & & & & & & & & \\
\hline $\begin{array}{l}\mathrm{F} 80,0-5 \mathrm{~cm}= \\
2003 \text {-present } \\
\text { (this study) }\end{array}$ & & 2785 & 5759 & 2974 & 28 & 26 & 15 & 11 & 27 \\
\hline $\begin{array}{l}\text { Mean of } 53 \text { cores } \\
\text { in Gotland basin } \\
\text { (Hille } 2005 ; \\
\text { Hille et al., 2005) }\end{array}$ & & 3379 & 6986 & 3607 & 34 & 32 & 6 & 26 & 27 \\
\hline
\end{tabular}

* Calculated from fluxes in budget of Gustafsson and Stigebrandt et al. (2007).

** Estimated from total P accumulation rates of Hille et al. (2005) and mean $\mathrm{P}_{\text {org }}$ : total P ratio of top $2 \mathrm{~cm}$ of F80, BY15 and LL19 (0.36, Table B1).

in the surface sediments in such intervals. Lateral transport of sedimentary material downslope into the deep basins of the Baltic (e.g., Emeis et al., 2002) may potentially contribute $\mathrm{P}$ via dissolution of $\mathrm{Fe}-\mathrm{P}$ transported across the redoxcline. While this flux remains poorly quantified, our calculated magnitude of the preferential remineralization flux is sufficient to explain $0.13-0.29 \mathrm{~g} \mathrm{~m}^{2} \mathrm{yr}^{-1}$ of the $0.30 \mathrm{~g} \mathrm{~m}^{2} \mathrm{yr}^{-1}$ "additional" $\mathrm{P}\left(\mathrm{R}_{\mathrm{Fe}}\right)$ observed during anoxic stagnations (Table 1). Considering the uncertainties involved, we may conclude that preferential remineralization accounts for a major proportion of $\mathrm{R}_{\mathrm{Fe}}$ during anoxic stagnations, with an additional contribution most likely derived from dissolution of laterally-transported Fe-P. These factors can also explain the scatter in the " $\mathrm{R}_{\mathrm{Fe}} \mathrm{vs}$. anoxic bottom increase" trend during variable redox stagnations (Fig. 10 in Gustafsson and Stigebrandt 2007).

In light of the proposed mechanisms for accelerated accumulation of $\mathrm{HPO}_{4}^{2-}$ in the deep waters, the relationship between total hypoxic area (A) and the total water column pool of $\mathrm{HPO}_{4}^{2-}$ (DIP) proposed by Conley et al. (2002) may be re-examined. Although the period 1970-2000 investigated by these authors encompasses several shorter multi- annual inflow-stagnation cycles, a clear secular trend is observed of contraction in the total hypoxic area from 19701993, followed by an expansion from 1994-2000, with the major inflow of 1993 acting as the switching point (Fig. 6a and Conley et al., 2002). The extended dataset of 19622006 presented in Conley et al. (2009a) confirms that this pattern forms part of a multidecadal oscillation in hypoxic area in the Baltic since the middle of the 20th century. Conley et al. (2002) showed that the net annual change in $\mathrm{A}(\Delta \mathrm{A})$ and $\Delta$ DIP are positively correlated in the 1970-2000 dataset, due to net uptake or release of $\mathrm{P}$ by sedimentary iron oxyhydroxides from one year to the next. However, the relationship between the raw values of A and DIP for the full 1970-2000 dataset is less conclusive (Fig. 6b), implying that the Fe-P interaction cannot fully explain the secular trends in DIP. When the data is divided into the intervals 1970 1993 and 1994-2000, it becomes clear that while the relationship between A and DIP during the expansion phase (1993-2000) is indeed strongly positive, during the contraction phase (1970-1993) the relationship is weakly negative (Fig. 6b). The switchbacks in the time series of the contraction phase contribute to the weakness of the correlation, and 
a

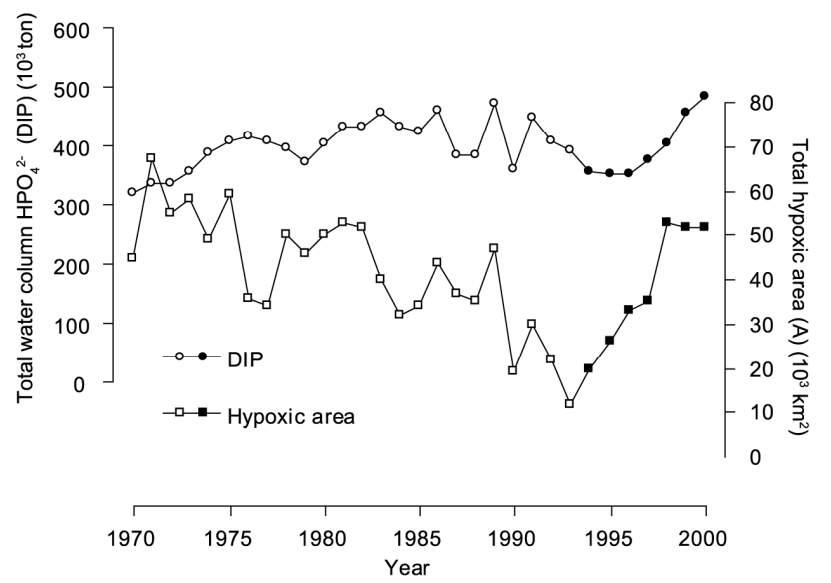

b

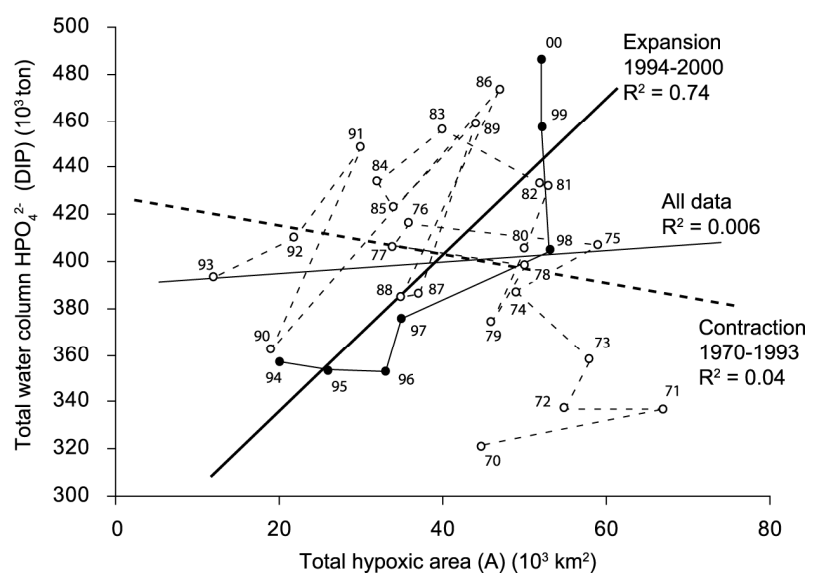

Fig. 6. (a) Time series of total hypoxic area of the Baltic ("A", square symbols), i.e. the area of sediments in contact with bottom waters of $<2 \mathrm{ml} \mathrm{L}^{-1} \mathrm{O}_{2}$, and the total pool of dissolved inorganic phosphate (DIP, circles). Both series averaged for January-March for each year from 1970-2000 (data from Table 1 in Conley et al., 2002). Open symbols indicate 1970-1993 "contraction" of hypoxic area, closed symbols represent 1994-2000 "expansion" phase. (b) Cross-plot of the same data. Trend for complete dataset shown as a fine solid line. Data points for 1970-1993 (open circles) are joined chronologically with a dashed line. Note the frequently positive relationship between annual changes in A and DIP but the overall negative trend for this interval (dashed trendline). Data points for 1994-2000 (filled circles) are joined chronologically with a solid line (heavy solid trendline represents 1994-2000 trend).

confirm the generally positive relationship between $\Delta \mathrm{A}$ and $\Delta$ DIP identified by Conley et al. (2002), with 15 of the 22 annual steps displaying a positive gradient. However, the results clearly indicate that during contraction of the hypoxic area on the multidecadal timescale from 1970-1993, a net trend towards higher DIP is observed, despite the ongoing uptake of $\mathrm{P}$ by iron oxyhydroxides as a larger area of surface sediments becomes oxic. This observation implies that during the contraction phase, release of $\mathrm{HPO}_{4}^{2-}$ into the water column below the halocline, via direct remineralization from organic matter in the surface sediments and in the water column itself, on balance outweighs the uptake of $\mathrm{P}$ by iron oxyhydroxides at shallower depths. Simply stated, although the volume of hypoxic water shrinks, the total mass of $\mathrm{HPO}_{4}^{2-}$ in the water column increases. Both preferential remineralization of $\mathrm{P}$ from organic matter and dissolution of Fe-P transported laterally into the deep basins may contribute to accelerated accumulation of $\mathrm{HPO}_{4}^{2-}$. In contrast, the strong positive correlation between A and DIP in the expansion phase of 1994-2000 can be explained by the fact that both organic matter remineralization and the dissolution of surface-sediment iron oxyhydroxides along the basin margins act in unison to release $\mathrm{HPO}_{4}^{2-}$ into the water column as the hypoxic area expands.

\subsection{Temporal variability in $P$ burial with expansion and contraction of hypoxic area}

The strong multidecadal oscillations in total hypoxic area may be expected to influence spatial patterns not only of $\mathrm{P}$ regeneration, but also of $\mathrm{P}$ burial, especially around the margins of the deep basins where redox conditions are most variable. Mort et al. (2010) showed that organic $\mathrm{P}\left(\mathrm{P}_{\text {org }}\right)$ is the dominant burial phase of reactive (non-detrital) $\mathrm{P}$ throughout most of the modern Baltic, due to the poor preservation of $\mathrm{Fe}-\mathrm{P}$ below the sediment surface and the lack of authigenic Ca-P formation within the upper 30 to $50 \mathrm{~cm}$ of the sediment column. To investigate the recent evolution of $\mathrm{P}_{\text {org }}$ burial in response to changes in hypoxia, we focus on dated sediment records from three sites (LF1, LF1.5 and LF3, Fig. 1) along a depth transect into the Fårö Deep in the central Baltic (details of the ${ }^{210} \mathrm{~Pb}$ age models are presented in Table $\mathrm{C} 1$ ). A long archive of water column monitoring data is available for comparison from site F80 in the central Fårö Deep, allowing reconstructions of water column oxygen conditions from 1910 onwards. Conditions in the central basin do not translate directly to those at equivalent depth along the basin margins, as shoaling of the halo/redoxcline in shallower waters dictates an offset towards lower oxygen concentrations at the shallower sites (see Fig. 16 in Al-Hamdani and Reker, 2007). However, the multidecadal trends in oxygen concentration in the 70-90 m depth range are expected to be qualitatively similar throughout the basin, making such a comparison valid. 
Water column oxygen concentrations at $70-90 \mathrm{~m}$ in the Fårö Deep declined from 1910-1970, crossing the threshold into hypoxia $\left(2 \mathrm{ml} \mathrm{L}^{-1}\right)$ in the lower part of the depth range. From 1970-1993, during contraction of the hypoxic area (and thus deepening of the water column redoxcline), oxygen concentrations increased, before declining again during expansion of the hypoxic area from 1994-2000. The accumulation rates of $\mathrm{P}_{\text {org }}$ at LF1, LF1.5 and LF3 show a clear inverse co-variation with oxygen concentrations throughout the 20th century, with maxima close to 1970 and minima close to 1992, confirming the observations of Mort et al. (2010) that $\mathrm{P}_{\text {org }}$ accumulation in Baltic Sea sediments increases with hypoxia. Although organic matter degradation within the upper sediments is expected to remove a portion of accumulated $\mathrm{P}_{\text {org }}$ prior to permanent burial, reactive transport modeling of organic matter degradation at these sites (unpublished results) suggest the influence of such breakdown at the current depth of the 1970-2000 interval is negligible, hence accumulation may be considered equivalent to burial. Furthermore, the accumulation rate of $\mathrm{C}_{\text {org }}$, and sedimentary $\mathrm{C}_{\text {org }}: \mathrm{P}_{\text {org }}$ ratios, show a roughly parallel evolution to that of $\mathrm{P}_{\text {org }}$ accumulation. This indicates that although enhanced preferential $P$ remineralization occurred at these sites during intervals of lower oxygen concentrations (thus maximum hypoxic area), net $P_{\text {org }}$ burial nevertheless increased due to enhanced burial of its host phase, organic matter.

The effects of the multidecadal expansion and contraction of the hypoxic area on $\mathrm{P}$ regeneration and burial are summarized in Fig. 8, in which the Fårö Deep is shown as representative for the deeper sections of the Baltic Proper. During intervals of maximum hypoxic area such as the early 1970s, the halocline and redoxcline were comparatively shallow, with hypoxia occurring below $\sim 70 \mathrm{~m}$ water depth in the central part of the basin. The zone of sediments along the basin margins containing Fe-P was therefore comparatively small, and LF1, LF1.5 and LF3 were all situated below the redoxcline. Hence, LF1, LF1.5 and LF3 in the early 1970s would qualify as Group 2 sites, characterized by the absence of Fe-P at the sediment surface, a high net rate of $\mathrm{P}_{\text {org }}$ burial, and enhanced preferential remineralization of $\mathrm{P}$ relative to $\mathrm{C}$. Conversely by 1992 , the halocline and redoxcline were displaced much deeper in the water column, qualifying LF1, LF1.5 and LF3 as Group 1 sites with Fe-P seasonally present in the surface sediments, a comparatively low net rate of $\mathrm{P}_{\text {org }}$ burial, and limited preferential remineralization of $\mathrm{P}$ relative to $\mathrm{C}$. However, despite the deeper redoxcline, the long stagnation of the bottom waters in the years leading up to 1992 generated a comparatively large total pool of water column DIP in the deepest part of the basin.

\subsection{Wider implications for P-driven eutrophication/ hypoxia feedbacks and basin-scale biogeochemical modeling}

Preferential remineralization of $\mathrm{P}$ from organic matter in the water column and sediments, and the consequent accumulation of $\mathrm{HPO}_{4}^{2-}$ below the halocline, clearly exert a strong control on the basinwide pool of DIP in the Baltic. However, since the total DIP pool largely consists of DIP stored in the deep waters, there remains much debate over its influence on $\mathrm{P}$ availability in the photic zone, and hence the efficiency of the positive feedback between $\mathrm{P}$ regeneration, eutrophication and sustained hypoxia. Upwards transport of $\mathrm{HPO}_{4}^{2-}$ across the halocline is predicted by the principles of turbulent diffusion (Gustafsson and Stigebrandt, 2007) and has been calculated to account for $60 \%$ of the annual replenishment of $\mathrm{HPO}_{4}^{2-}$ to surface waters (Vahtera et al., 2007). However, recent evidence suggests that up to $40-60 \%$ of the flux estimated from the $\left[\mathrm{HPO}_{4}^{2-}\right]$ gradient may in fact be trapped and recycled by particulate iron and manganese oxyhydroxides in the water column (Turnewitsch and Pohl, 2010). This process may contribute to the low correlation observed between winter $\mathrm{HPO}_{4}^{2-}$ concentrations above and below the halocline at sites in the open Baltic (Lilover and Stips, 2008). Furthermore, the physical mechanisms determining $\mathrm{P}$ transport to the surface, ie. wind-driven mixing in winter (Janssen et al., 2004) and summer upwelling along coastal margins (Nausch et al., 2009) are sensitive to climatic parameters and thus vary on multiannual to multidecadal timescales.

Changes in the spatial distribution of the deep-water DIP pool (Fig. 8) may influence its accessibility to vertical transport processes such as mixing and upwelling, and thus may be equally as important as the size of the pool itself in determining the total rate of $\mathrm{P}$ supply to the surface waters. A major challenge for future biogeochemical modeling of the Baltic is thus to unravel how the two contrasting - and naturally forced - states presented in Fig. 8 differ in their capability to sustain eutrophication and hypoxia. Especially with regards to the planning of hypoxia remediation strategies (Conley et al., 2009b), knowledge of the expected response of the system to changes in total hypoxic area is crucial. The enhanced $\mathrm{C}_{\text {org }}$ burial observed along the deep basin margins during intervals of maximum hypoxic area (Figs. 7, 8) is likely a combined signal, both of deteriorating redox conditions and of higher export productivity, analogous to the mechanisms by which Mediterranean sapropel sediments are formed (e.g., de Lange et al., 2008). If so, intervals of maximum hypoxic area such as the early 1970 s may well be characterized by a more efficient $P$ regeneration-eutrophicationhypoxia feedback loop than intervals of minimum hypoxic area, with all fluxes in the $\mathrm{P}$ cycle accelerating despite the smaller total DIP pool in the water column. This would imply that the accessibility of the DIP pool (which is greater due to its shoaling during intervals of maximum hypoxic area) 


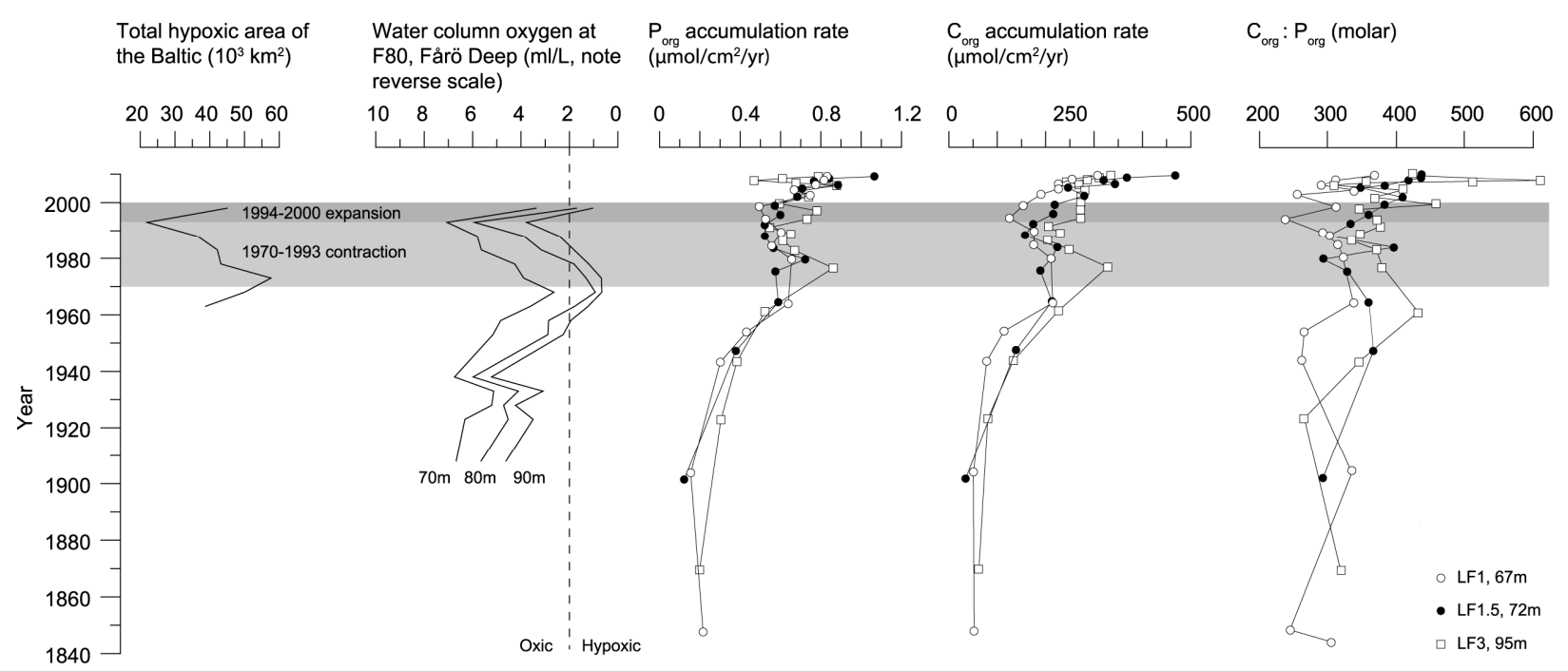

Fig. 7. Time series of $C_{\text {org }}$ and $P_{\text {org }}$ accumulation rates, and $C_{\text {org }} / P_{\text {org }}$, at sites LF1, LF1.5 and LF3 on the margins of the Fårö Deep in the central Baltic, and relevant water column oxygen data. $\mathrm{C}_{\text {org }}$ and $\mathrm{P}_{\text {org }}$ accumulation rates were calculated from ${ }^{210} \mathrm{~Pb}$-derived mass accumulation rates (estimated using a Constant Rate of ${ }^{210} \mathrm{~Pb}$ Supply (CRS) model (Boer et al., 2006) and $\mathrm{C}_{\text {org }}$ and $\mathrm{P}_{\text {org }}$ contents). Total hypoxic area data from Conley et al. (2009) and water column oxygen concentrations at site F80 from the Baltic Sea Environmental Database at Stockholm University are plotted as 5 year binned mean values.

indeed outweighs the size of the pool in determining the net upwards flux of $\mathrm{P}$ to the surface waters.

\section{Conclusions}

A comprehensive coring survey has facilitated an unprecedented investigation of the controls on regeneration and burial of $\mathrm{P}$ throughout the Baltic Sea. The network of porewater data provide a snapshot of conditions during the current stagnation interval (2003-present), and reveal a strong depth-dependence of the processes controlling regeneration of $\mathrm{P}$ from the sediments. Sites of $\leq 90 \mathrm{~m}$ water depth currently display evidence for the interaction between $\mathrm{P}$ and iron oxhydroxides in the surface sediments, confirming the earlier work of Mort et al. (2010). Seasonal variability in bottom-water redox conditions at such sites results in a strong annual cycle in the efflux of $\mathrm{P}$, with maximum release during the most reducing months when iron oxhydroxides reductively dissolve. In contrast, sites below $90 \mathrm{~m}$ display a continuous efflux of $\mathrm{P}$, reflecting degradation of sedimentary organic matter. Moreover, the rate of $\mathrm{P}$ regeneration (relative to $\mathrm{C}$ and $\mathrm{N}$ ) from degrading organic matter is controlled by the ambient redox conditions, and hence is itself depth-dependent, with maximum preferential $\mathrm{P}$ remineralization occurring in the deep basins. Such preferential $P$ remineralization leads to depletion of the diffusive flux ratio of $\mathrm{NH}_{4}^{+} / \mathrm{HPO}_{4}^{2-}$, and enrichment of sedimentary $\mathrm{N}_{\text {tot }}: \mathrm{P}_{\text {org }}$ and $\mathrm{C}_{\text {org }}: \mathrm{P}_{\text {org }}$, with increasing water depth. The data suggest a roughly two-fold enrichment of the $\mathrm{N}_{\text {tot }}: \mathrm{P}_{\text {org }}$ ratio of organic matter from its original Redfield proportions during descent through the water column, followed by further enrichment after accumulation at the sediment-water interface. These processes lead to a substantial build-up of excess $\mathrm{P}$ in the water column, which is underestimated by existing Redfield-based modeling of biogeochemical cycles during previous stagnation intervals. Furthermore, the magnitude of preferential remineralization of $\mathrm{P}$ in the deep basins was great enough to generate a net increase in the total water column pool of DIP during contraction of the hypoxic area from 1970-1993, despite the large scale sequestration of $\mathrm{P}$ into iron oxyhydroxides at shallower depths during this time.

Burial of reactive $\mathrm{P}$ in the Baltic takes place principally as organic $\mathrm{P}$, and the rate of organic $\mathrm{P}$ burial along the margins of the deep basins is redox dependent, with higher burial during intervals of more reducing conditions. Expansion of the total hypoxic area on the multidecadal timescale thus leads to expansion of the area of enhanced burial of organic $\mathrm{P}$, despite a simultaneous increase in the rate of preferential remineralization of $\mathrm{P}$ from organic matter and the large-scale dissolution of $\mathrm{P}$ associated with iron oxyhydroxides. This may imply an accelerated $\mathrm{P}$ cycle during intervals of maximum hypoxic area, in which the rates of $\mathrm{P}$ incorporation into organic matter, regeneration from and burial within the sediments are all enhanced. Such a scenario may be supported physically by efficient upwards transport of deep water $\mathrm{HPO}_{4}^{2-}$ across the shallow halocline present during these intervals. 


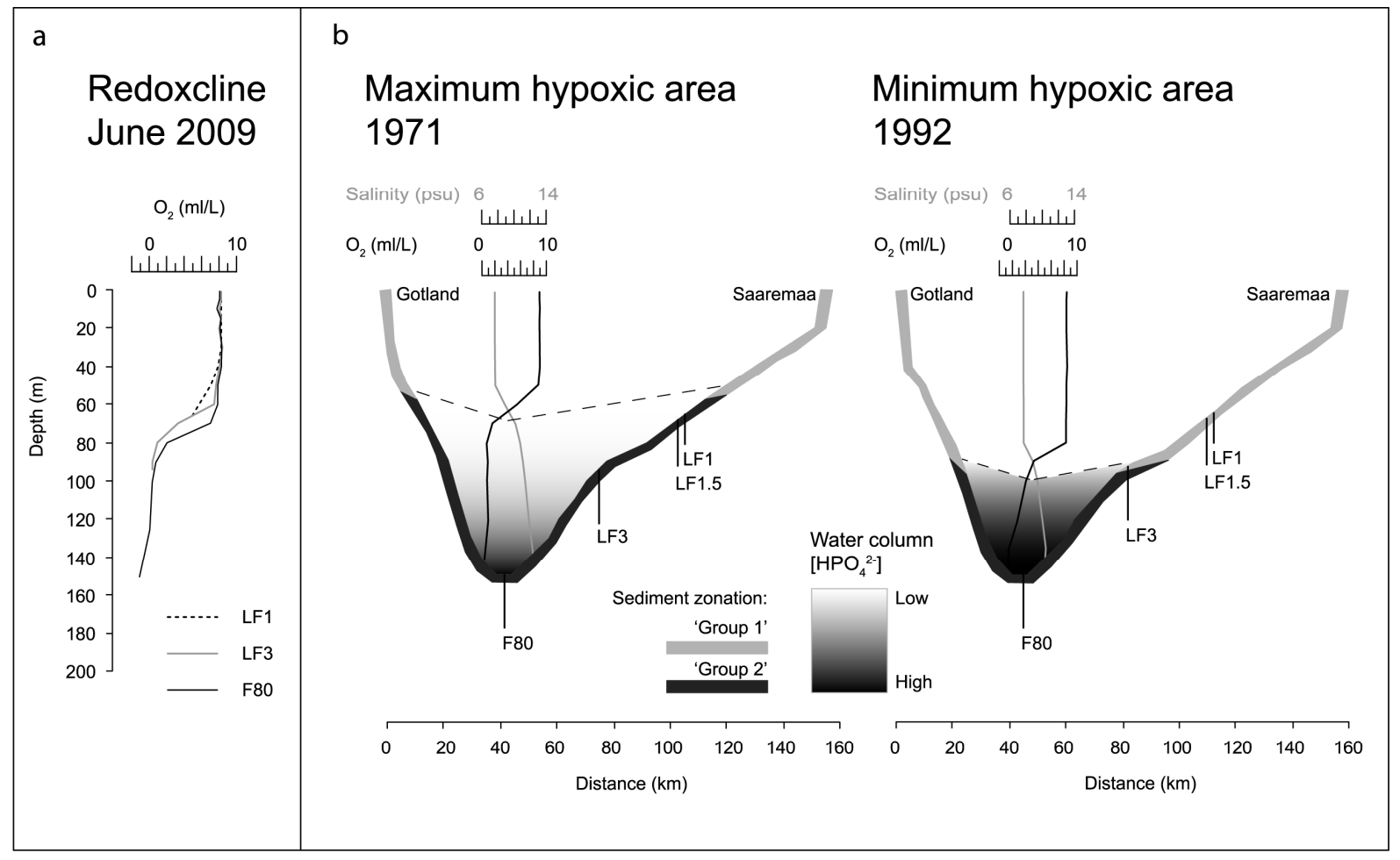

C

\begin{tabular}{|c|l|l|l|}
\hline Zone & Presence of Fe-P & Permanent burial rate of $\mathbf{P}_{\text {org }}$ & Remineralization rate of $\mathbf{P}_{\text {org }}$ (relative to $\mathbf{C}_{\text {org }}$ ) \\
\hline 'Group 1' & $\begin{array}{l}\text { Seasonal retention } \\
\text { and release in } \\
\text { surface sediments }\end{array}$ & $\begin{array}{l}\text { Low: efficient oxic degradation } \\
\text { releases } \mathrm{P} \text { from organic matter, } \\
\text { to be trapped as Fe-P in surface } \\
\text { sediments }\end{array}$ & $\begin{array}{l}\text { Low: despite efficient degradation of } \\
\text { organic matter, oxic degradation pathways } \\
\text { favor retention of } P_{\text {org }} \text { relative to } C_{\text {org }}\end{array}$ \\
'Group 2' & Absent & $\begin{array}{l}\text { High: inefficient anoxic degradation } \\
\text { of organic matter }\end{array}$ & $\begin{array}{l}\text { High: anoxic degradation pathways favor } \\
\text { release of } P \text { from sediments }\end{array}$ \\
\hline
\end{tabular}

Fig. 8. (a) Water column oxygen concentrations measured during the R/V Aranda cruise of May/June 2009 at sites LF1, LF3 and F80 along a depth transect into the Fårö Deep between the islands of Gotland and Saaremaa, showing the vertical offset of the redoxcline between central (F80) and marginal (LF1) sites. (b) Scaled cross-sectional sketches through Fårö Deep in 1971 and 1992 (simplified bathymetry from Data Assimilation System of Baltic Environmental Database, Stockholm University, depth scale as for (a)), showing water column salinity and oxygen profiles from F80 (also known as BY20, data from Baltic Environmental Database) in the month of February (chosen for comparable data availability). With the exception of F80, sites are positioned accurately by depth. The simplified bathymetry aliases the true depth of F80 (191 m, Fig. 2) and generates minor lateral offsets from true position of all sites. Dashed lines show approximate position of hypoxia threshold $\left(\mathrm{O}_{2}=2 \mathrm{ml} \mathrm{L}^{-1}\right)$ based on profiles at F80 and assumption of $15 \mathrm{~m}$ vertical offset of redoxcline between F80 and LF1 (see (a)). Shading in water column below halo/redoxcline qualitatively represents deep water [ $\mathrm{HPO}_{4}^{2-}$ ]. Sediment zones are divided based on the assumption that iron oxyhydroxides are absent from surface sediments below a threshold of oxygen stress which may be spatially variable but generally deeper than that of bottom water hypoxia. (c) Table summarizing characteristics of sediment zones with respect to the phosphorus cycle. 
Table A1. Concentrations of porewater species in $\mu \mathrm{mol} \mathrm{L}^{-1}$ ( $\mathrm{R}=$ sampled with rhizons $)$ and bottom water oxygen concentrations in $\mathrm{mlL}^{-1}$. Sub-zero oxygen concentrations are estimated from hydrogen sulfide concentrations using the ratio $1 \mathrm{~mol} \mathrm{H}_{2} \mathrm{~S}=2 \mathrm{~mol} \mathrm{O}_{2}$ (see Fonselius, 1981).

\begin{tabular}{|c|c|c|c|c|c|}
\hline Core & $\begin{array}{l}\text { Sample } \\
\text { mid-depth } \\
(\mathrm{cm}, \\
0=\text { bottom } \\
\text { water) }\end{array}$ & $\mathrm{NH}_{4}$ & $\mathrm{SO}_{4}$ & $\mathrm{HPO}_{4}$ & $\mathrm{Fe}$ \\
\hline
\end{tabular}

\begin{tabular}{llllll}
\hline LF1 & & & & \\
Bottom water & 0 & 50 & 6283 & 2 & 0 \\
$\mathrm{O}_{2}=4.77 \mathrm{ml} \mathrm{L}^{-1}$ & 0.25 & 53 & 5535 & 106 & 257 \\
& 0.75 & 76 & 6276 & 84 & 209 \\
& 1.25 & 91 & 6347 & 79 & 143 \\
& 1.75 & 108 & 6362 & 108 & 140 \\
& 2.5 & 119 & 5952 & 78 & 53 \\
& 3.5 & 144 & 6005 & 95 & 44 \\
& 4.5 & 165 & 5649 & 97 & 20 \\
& 5.5 & 167 & 4869 & 109 & 4 \\
& 6.5 & 186 & 4901 & 115 & 0 \\
& 7.5 & 187 & 4516 & 119 & 0 \\
& 8.5 & 229 & 4206 & 121 & 0 \\
& 9.5 & 236 & 4772 & 125 & 0 \\
& 11 & 252 & 4830 & 126 & 0 \\
& 13 & 235 & 4411 & 125 & 0 \\
& 15 & 244 & 4017 & 127 & 0 \\
& 17 & 250 & 3890 & 129 & 0 \\
& 19 & 246 & 3831 & 128 & 0 \\
& 21 & 195 & 3329 & 127 & 0 \\
& 23 & 260 & 4086 & 128 & 0 \\
& 25 & 239 & 3930 & 128 & 0
\end{tabular}

\begin{tabular}{llllll} 
LF1.5 & & & & & \\
Bottom water & 0 & 19 & 6312 & 2 & 0 \\
$\mathrm{O}_{2}=3.83 \mathrm{ml} \mathrm{L}^{-1}$ & 0.25 & 77 & 6220 & 51 & 9 \\
& 0.75 & 123 & 6287 & 84 & 6 \\
& 1.25 & 147 & 5727 & 92 & 9 \\
& 1.75 & 187 & 5864 & 112 & 1 \\
& 2.5 & 217 & 5167 & 124 & 1 \\
& 3.5 & 252 & 5340 & 120 & 0 \\
& 4.5 & 270 & 5057 & 117 & 0 \\
& 5.5 & 260 & 4162 & 116 & 0 \\
& 6.5 & 297 & 4286 & 119 & 1 \\
& 7.5 & 340 & 3816 & 125 & 0 \\
& 8.5 & 377 & 4370 & 128 & 0 \\
& 9.5 & 397 & 4083 & 134 & 0 \\
& 11 & 436 & 3866 & 144 & 0 \\
& 13 & 373 & 3042 & 151 & 0 \\
& 15 & 396 & 3018 & 158 & 0 \\
17 & 377 & 2572 & 162 & 0 \\
& 19 & 429 & 3173 & 165 & 0 \\
& 21 & 444 & 3258 & 171 & 0 \\
& 23 & 432 & 3130 & 171 & 0 \\
25 & 393 & 2797 & 174 & 2 \\
\hline
\end{tabular}

\begin{tabular}{|c|c|c|c|c|c|}
\hline Core & $\begin{array}{l}\text { Sample } \\
\text { mid-depth } \\
(\mathrm{cm}, \\
0=\text { bottom } \\
\text { water) }\end{array}$ & $\mathrm{NH}_{4}$ & $\mathrm{SO}_{4}$ & $\mathrm{HPO}_{4}$ & $\mathrm{Fe}$ \\
\hline \multicolumn{6}{|l|}{ BCS(III) 10} \\
\hline Bottom water & 0 & 42 & 8050 & 3 & 0 \\
\hline \multirow{22}{*}{$\mathrm{O}_{2}=1.19 \mathrm{ml} \mathrm{L}^{-1}$} & 0.25 & 101 & 8371 & 58 & 19 \\
\hline & 0.75 & 138 & 8196 & 76 & 9 \\
\hline & 1.25 & 170 & 8226 & 84 & 0 \\
\hline & 1.75 & 205 & 7827 & 94 & 0 \\
\hline & 2.5 & 228 & 7238 & 109 & 0 \\
\hline & 3.5 & 287 & 6895 & 117 & 0 \\
\hline & 4.5 & 343 & 6624 & 130 & 0 \\
\hline & 5.5 & 362 & 5721 & 139 & 0 \\
\hline & 6.5 & 391 & 5966 & 152 & 0 \\
\hline & 7.5 & 446 & 5405 & 164 & 0 \\
\hline & 8.5 & 468 & 5024 & 176 & 0 \\
\hline & 9.5 & 503 & 4881 & 179 & 0 \\
\hline & 11 & 526 & 4766 & 193 & 0 \\
\hline & 13 & 527 & 3569 & 207 & 0 \\
\hline & 15 & 569 & 3676 & 217 & 0 \\
\hline & 17 & 585 & 3266 & 219 & 0 \\
\hline & 19 & 651 & 3109 & 236 & 0 \\
\hline & 21 & 657 & 2661 & 240 & 0 \\
\hline & 23 & 550 & 1906 & 248 & 0 \\
\hline & 25 & 759 & 2575 & 245 & 0 \\
\hline & 27 & 704 & 2444 & 251 & 0 \\
\hline & 29 & 717 & 1929 & 254 & 0 \\
\hline \multicolumn{6}{|l|}{ BY5 } \\
\hline Bottom water & 0 & 6 & 13310 & 2 & 0 \\
\hline \multirow[t]{25}{*}{$\mathrm{O}_{2}=0.09 \mathrm{ml} \mathrm{L}^{-1}$} & 0.25 & 108 & 13700 & 26 & 2 \\
\hline & 0.75 & 90 & 12614 & 18 & 0 \\
\hline & 1.25 & 106 & 12907 & 18 & 0 \\
\hline & 1.75 & 148 & 12443 & 65 & 0 \\
\hline & 2.5 & 167 & 12017 & 75 & 0 \\
\hline & 3.5 & 200 & 12004 & 79 & 0 \\
\hline & 4.5 & 217 & 11440 & 84 & 0 \\
\hline & 5.5 & 247 & 11885 & 83 & 0 \\
\hline & 6.5 & 229 & 10340 & 86 & 0 \\
\hline & 7.5 & 221 & 9607 & 92 & 0 \\
\hline & 8.5 & 218 & 8221 & 92 & 0 \\
\hline & 9.5 & 252 & 9650 & 95 & 0 \\
\hline & 11 & 272 & 10189 & 96 & 0 \\
\hline & 13 & 239 & 7865 & 102 & 0 \\
\hline & 15 & 274 & 9373 & 103 & 0 \\
\hline & 17 & 280 & 10283 & 106 & 0 \\
\hline & 19 & 293 & 11221 & 108 & 0 \\
\hline & 21 & 283 & 9407 & 111 & 0 \\
\hline & 23 & 235 & 7449 & 117 & 0 \\
\hline & 25 & 239 & 7090 & 121 & 0 \\
\hline & 27 & 285 & 10144 & 122 & 0 \\
\hline & 29 & 293 & 11026 & 126 & 0 \\
\hline & 31 & 296 & 9504 & 127 & 0 \\
\hline & 33 & 294 & 8078 & 130 & 0 \\
\hline & 35 & 295 & 8571 & 132 & 0 \\
\hline
\end{tabular}


Table A1. Continued.

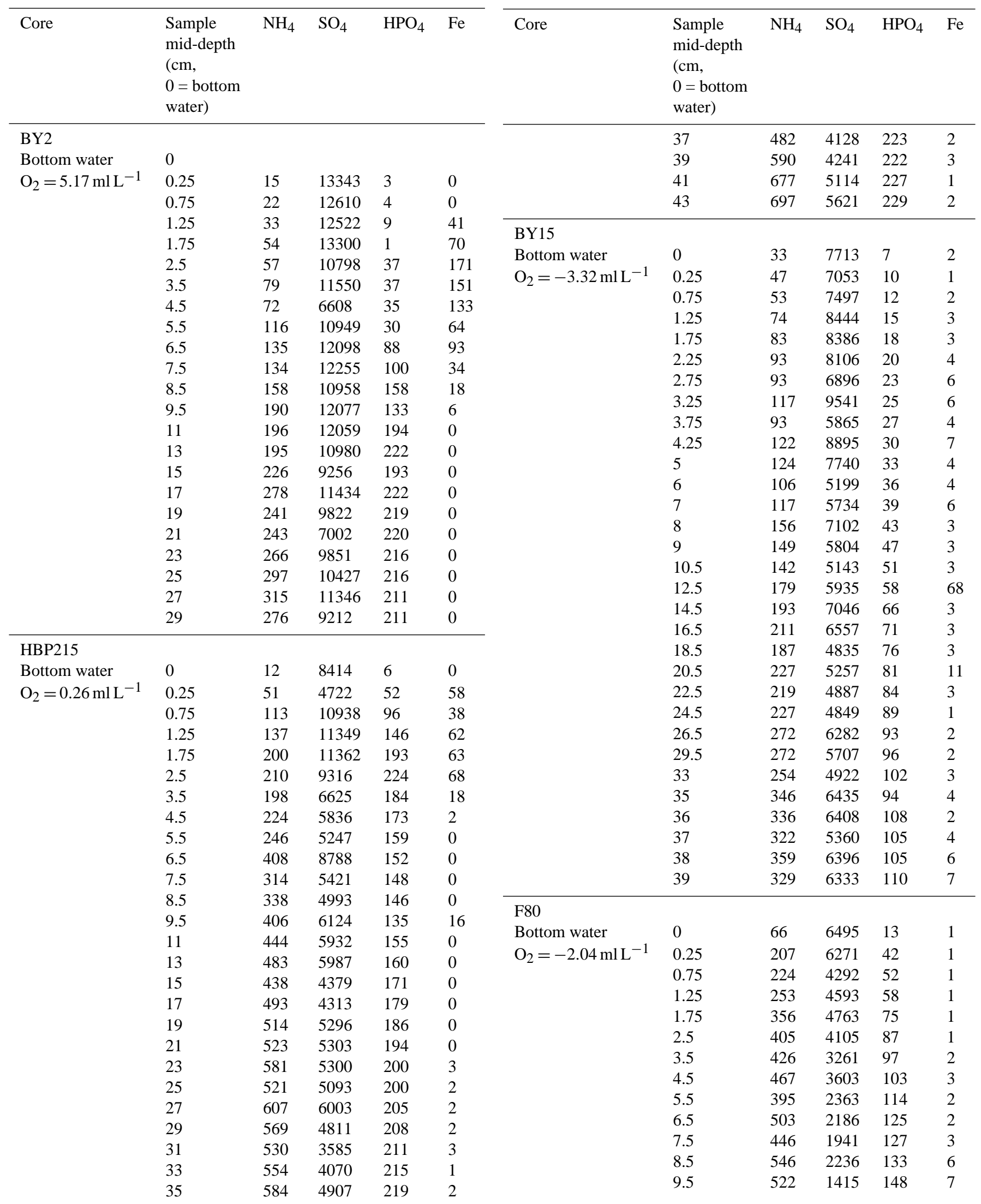


Table A1. Continued.

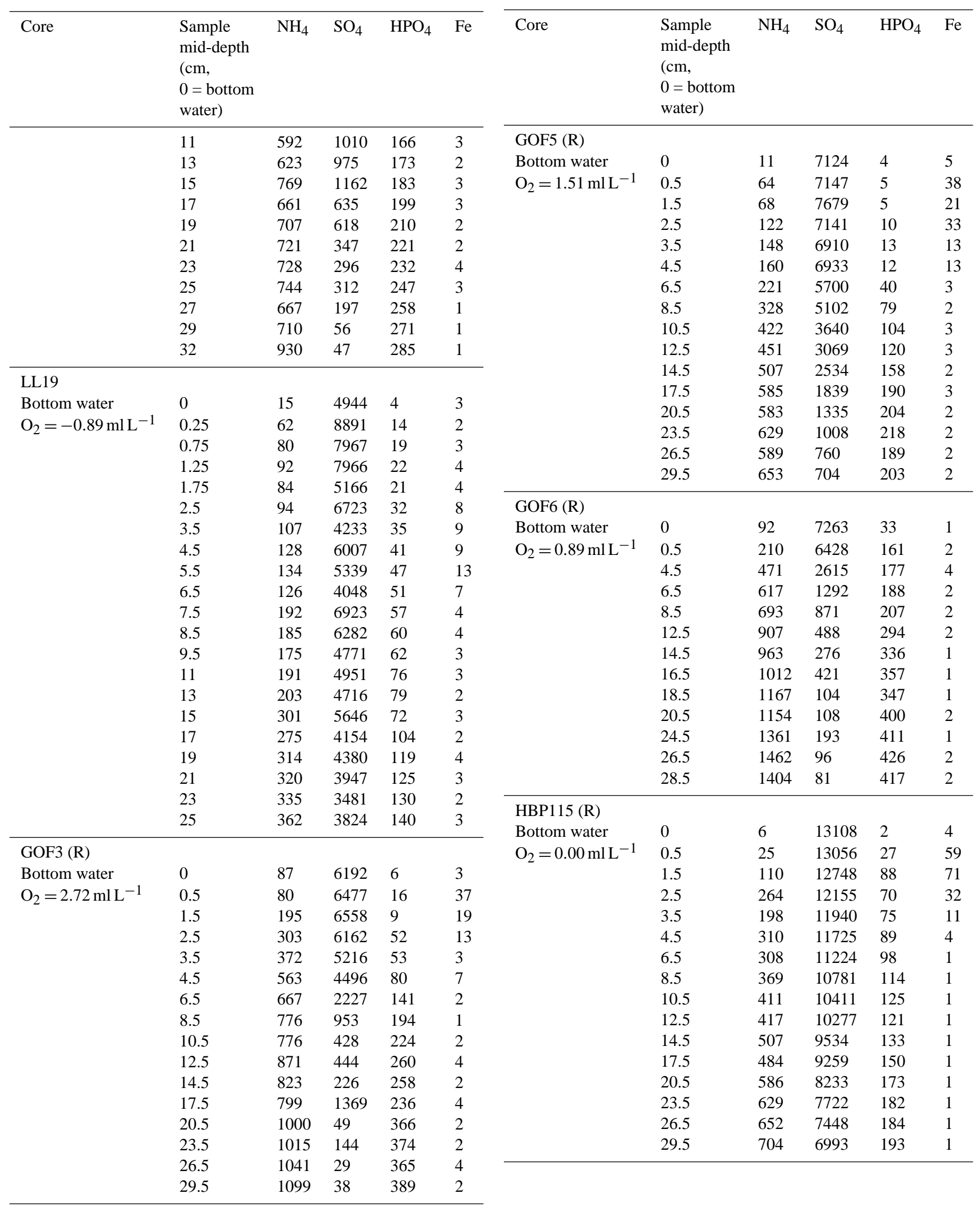


Table A1. Continued.

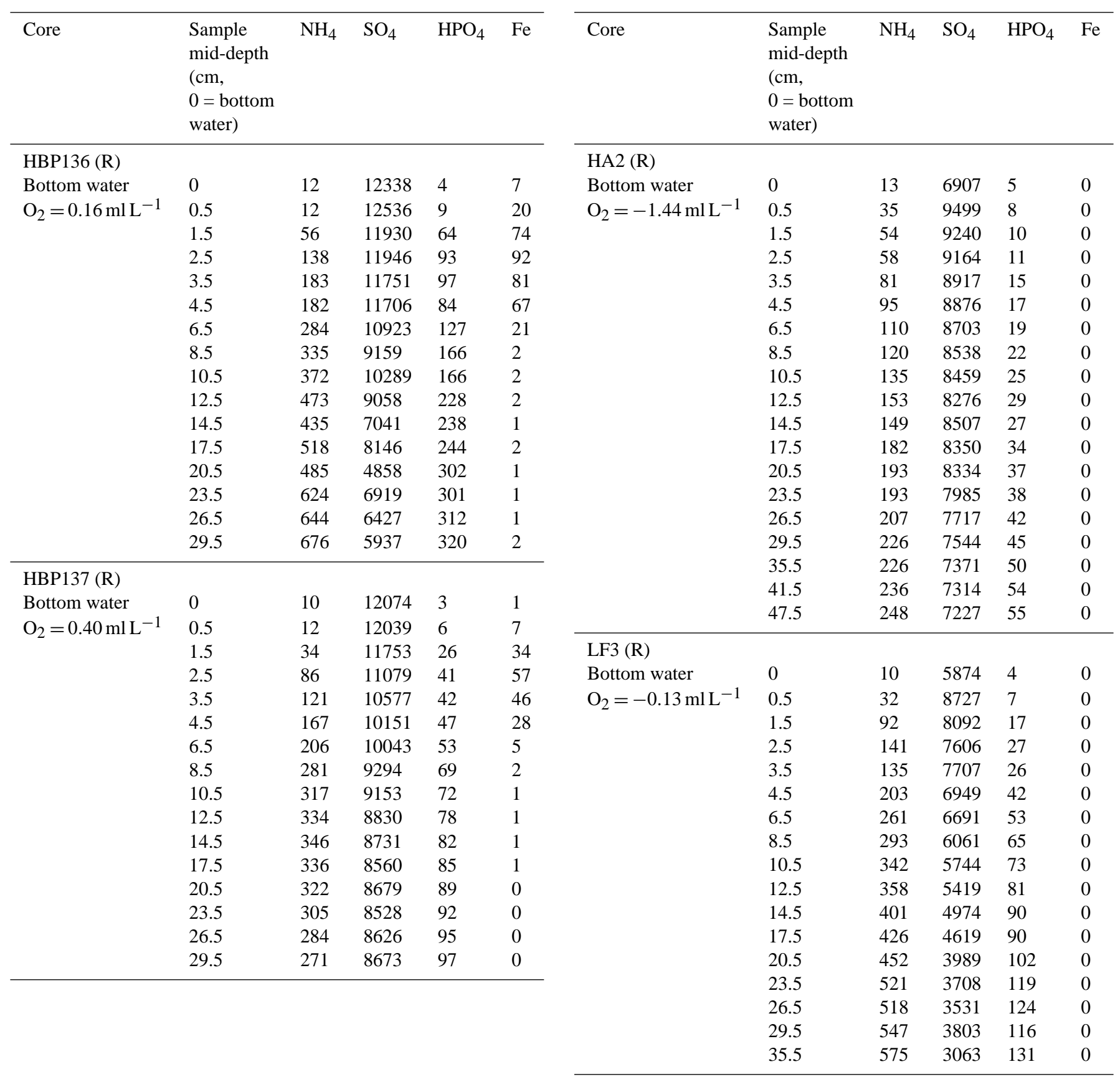


Table B1. Solid-phase parameters, in $\mu \mathrm{molg}^{-1}$ salt-free dry sediment.

\begin{tabular}{|c|c|c|c|c|c|c|c|c|c|c|c|c|c|}
\hline Core & $\begin{array}{l}\text { Sample } \\
\text { mid-depth } \\
(\mathrm{cm})\end{array}$ & $\mathrm{N}_{\text {tot }}$ & $\mathrm{C}_{\text {org }}$ & $\mathrm{Fe}-\mathrm{P}$ & $\mathrm{P}_{\text {org }}$ & $\begin{array}{l}\text { Total P } \\
\text { (ICP- } \\
\text { OES) }\end{array}$ & Core & $\begin{array}{l}\text { Sample } \\
\text { mid-depth } \\
(\mathrm{cm})\end{array}$ & $\mathrm{N}_{\text {tot }}$ & $\mathrm{C}_{\text {org }}$ & $\mathrm{Fe}-\mathrm{P}$ & $P_{\text {org }}$ & $\begin{array}{l}\text { Total P } \\
\text { (ICP- } \\
\text { OES) }\end{array}$ \\
\hline BY2 & & & & & & & & 6.5 & 181 & 1572 & & 5 & 21 \\
\hline \multirow[t]{23}{*}{ June } & 0.25 & 519 & 4745 & 41 & 13 & 69 & & 7.5 & 152 & 1367 & & 5 & 20 \\
\hline & 0.75 & 483 & 4493 & 45 & 13 & 68 & & 8.5 & 208 & 1894 & & 5 & 21 \\
\hline & 1.25 & 431 & 4040 & 66 & 12 & 80 & & 9.5 & 194 & 1754 & & 6 & 20 \\
\hline & 1.75 & 464 & 4374 & 72 & 11 & 75 & & 11 & 176 & 1629 & & 5 & 22 \\
\hline & 2.5 & 452 & 4272 & 27 & 7 & 53 & & 13 & 232 & 2164 & & 6 & 25 \\
\hline & 3.5 & 466 & 4397 & 25 & 11 & 51 & & 15 & 229 & 2136 & & 6 & 23 \\
\hline & 4.5 & 444 & 4243 & 11 & 12 & 36 & & 17 & 83 & 780 & & 3 & 17 \\
\hline & 5.5 & 438 & 4159 & 11 & 10 & 37 & & 19 & 107 & 997 & & 3 & 17 \\
\hline & 6.5 & 447 & 4257 & 13 & 11 & 40 & & 21 & 104 & 1005 & & 3 & 19 \\
\hline & 7.5 & 426 & 4098 & 7 & 10 & 34 & & 23 & 102 & 997 & & 4 & 18 \\
\hline & 8.5 & 418 & 4062 & 7 & 11 & 34 & & 25 & 199 & 1928 & & 4 & 20 \\
\hline & 9.5 & 425 & 4111 & 7 & 10 & 36 & \multirow{23}{*}{ LF3 } & & & & & & \\
\hline & 11 & 386 & 3720 & 5 & 10 & 32 & & & & & & & \\
\hline & 13 & 374 & 3638 & 4 & 9 & 30 & & 0.25 & 844 & 7948 & & 19 & 54 \\
\hline & 15 & 370 & 3598 & 4 & 9 & 30 & & 0.75 & 727 & 7101 & & 14 & 43 \\
\hline & 17 & 448 & 3939 & 3 & 9 & 29 & & 1.25 & 632 & 6158 & & 10 & 36 \\
\hline & 19 & 404 & 3861 & 4 & 9 & 28 & & 1.75 & 493 & 4669 & & 13 & 32 \\
\hline & 21 & 394 & 3848 & 4 & 9 & 30 & & 2.5 & 476 & 4524 & & 15 & 31 \\
\hline & 23 & 284 & 2807 & 4 & 9 & 31 & & 3.5 & 486 & 4570 & & 11 & 31 \\
\hline & 25 & 394 & 3905 & 5 & 10 & 30 & & 4.5 & 461 & 4357 & & 12 & 31 \\
\hline & 27 & 413 & 4068 & 4 & 9 & 31 & & 5.5 & 462 & 4309 & & 9 & 30 \\
\hline & 29 & 414 & 4104 & 5 & 10 & $\begin{array}{l}51 \\
33\end{array}$ & & 6.5 & 458 & 4331 & & 12 & 30 \\
\hline & & & 4104 & $J$ & 10 & & & 7.5 & 448 & 4360 & & 12 & 29 \\
\hline \multirow[t]{22}{*}{ LF1 } & & & & & & & & 8.5 & 326 & 3054 & & 8 & 26 \\
\hline & 0.25 & 257 & 2322 & & 6 & 38 & & 9.5 & 342 & 3260 & & 9 & 26 \\
\hline & 0.75 & 235 & 2039 & & 7 & 26 & & 11 & 252 & 2296 & & 7 & 23 \\
\hline & 1.25 & 211 & 1852 & & 6 & 26 & & 13 & 290 & 2683 & & 7 & 24 \\
\hline & 1.75 & 214 & 1881 & & 6 & 25 & & 15 & 471 & 4584 & & 12 & 30 \\
\hline & 2.5 & 183 & 1609 & & 6 & 22 & & 17 & 390 & 3809 & & 9 & 27 \\
\hline & 3.5 & 129 & 1181 & & 4 & 19 & & 19 & 275 & 2511 & & 7 & 24 \\
\hline & 4.5 & 97 & 887 & & 4 & 17 & & 21 & 235 & 2082 & & 8 & 22 \\
\hline & 5.5 & 134 & 1228 & & 4 & 19 & & 23 & 200 & 1713 & & 5 & 23 \\
\hline & 6.5 & 132 & 1224 & & 4 & 18 & & 26 & 204 & 1770 & & 5 & 22 \\
\hline & 7.5 & 217 & 2006 & & 6 & 21 & & 30 & 245 & 2225 & & 7 & 24 \\
\hline & 8.5 & 245 & 2262 & & 7 & 22 & \multirow{12}{*}{ F80 } & & & & & & \\
\hline & 9.5 & 137 & 1292 & & 5 & 19 & & & & & & & \\
\hline & 11 & 122 & 1176 & & 4 & 19 & & 0.25 & 1133 & 11690 & & & \\
\hline & 13 & 98 & 946 & & 3 & 15 & & 0.75 & 1248 & 13100 & & 18 & 65 \\
\hline & 15 & 84 & 821 & & 3 & 17 & & 1.25 & 1102 & 11873 & & 25 & 58 \\
\hline & 17 & 96 & 966 & & 3 & 18 & & 1.75 & 1139 & 12510 & & 33 & 60 \\
\hline & 19 & 73 & 733 & & 3 & 16 & & 2.5 & 1215 & 13686 & & 27 & 63 \\
\hline & 21 & 60 & 611 & & 2 & 17 & & 3.5 & 1060 & 11283 & & & 56 \\
\hline & 23 & 84 & 888 & & 3 & 17 & & 4.5 & 968 & 9694 & & 22 & 50 \\
\hline & 25 & 67 & 688 & & 5 & $\begin{array}{l}17 \\
17\end{array}$ & & 5.5 & 733 & 7575 & & 17 & 41 \\
\hline & & 01 & 000 & & 5 & $1 /$ & & 6.5 & 790 & 8319 & & 18 & 43 \\
\hline \multirow[t]{9}{*}{ LF1.5 } & & & & & & & & 7.5 & 840 & 8923 & & 20 & 46 \\
\hline & 0.25 & 534 & 4943 & & 11 & 46 & & 8.5 & 733 & 7836 & & 18 & 46 \\
\hline & 0.75 & 494 & 4119 & & 9 & 34 & & 9.5 & 732 & 7661 & & 19 & 43 \\
\hline & 1.25 & 438 & 3787 & & 9 & 33 & & 11 & 734 & 7794 & & 18 & 38 \\
\hline & 1.75 & 467 & 3974 & & 10 & 36 & & 13 & 728 & 7614 & & 26 & 41 \\
\hline & 2.5 & 308 & 2680 & & 8 & 28 & & 15 & 665 & 6803 & & 18 & 44 \\
\hline & 3.5 & 352 & 3024 & & 7 & 29 & & 17 & 677 & 6877 & & 16 & 40 \\
\hline & 4.5 & 250 & 2171 & & 6 & 24 & & 19 & 721 & 7356 & & 14 & 39 \\
\hline & 5.5 & 241 & 2033 & & 6 & 23 & & 21 & 644 & 6595 & & 11 & 38 \\
\hline
\end{tabular}


Table B1. Continued.

\begin{tabular}{|c|c|c|c|c|c|c|}
\hline Core & $\begin{array}{l}\text { Sample } \\
\text { mid-depth } \\
(\mathrm{cm})\end{array}$ & $\mathrm{N}_{\text {tot }}$ & $\mathrm{C}_{\text {org }}$ & Fe-P & $\mathrm{P}_{\text {org }}$ & $\begin{array}{l}\text { Total P } \\
\text { (ICP- } \\
\text { OES) }\end{array}$ \\
\hline & 23 & 595 & 6296 & & 15 & 38 \\
\hline & 25 & 223 & 2448 & & 7 & 36 \\
\hline & 27 & 184 & 2122 & & 6 & 36 \\
\hline & 29 & 188 & 2152 & & 9 & 44 \\
\hline & 32 & 172 & 2170 & & 8 & 30 \\
\hline \multicolumn{7}{|l|}{ LL19 } \\
\hline & 0.25 & 906 & 9857 & & 14 & 55 \\
\hline & 0.75 & 1022 & 11376 & & 17 & 58 \\
\hline & 1.25 & 979 & 10721 & & 19 & 55 \\
\hline & 1.75 & 913 & 9729 & & 16 & 51 \\
\hline & 2.5 & 789 & 8180 & & 16 & 43 \\
\hline & 3.5 & 686 & 7357 & & 14 & 41 \\
\hline & 4.5 & 649 & 7031 & & 14 & 40 \\
\hline & 5.5 & 664 & 7055 & & 12 & 44 \\
\hline & 6.5 & 602 & 6326 & & 11 & 41 \\
\hline & 7.5 & 605 & 6443 & & 13 & 39 \\
\hline & 8.5 & 554 & 5983 & & & \\
\hline & 9.5 & 282 & 3119 & & 7 & 31 \\
\hline & 11 & 204 & 2394 & & 6 & 28 \\
\hline & 13 & 172 & 2063 & & 6 & 27 \\
\hline & 15 & 153 & 1843 & & 5 & 28 \\
\hline & 17 & 147 & 1781 & & 5 & 26 \\
\hline & 19 & 147 & 1807 & & 5 & 25 \\
\hline & 21 & 137 & 1628 & & 5 & 26 \\
\hline & 23 & 142 & 1642 & & 5 & 26 \\
\hline & 25 & 137 & 1602 & & 6 & 27 \\
\hline
\end{tabular}

\begin{tabular}{|c|c|c|c|c|c|c|}
\hline Core & $\begin{array}{l}\text { Sample } \\
\text { mid-depth } \\
(\mathrm{cm})\end{array}$ & $\mathrm{N}_{\text {tot }}$ & $\mathrm{C}_{\text {org }}$ & $\mathrm{Fe}-\mathrm{P}$ & $\mathrm{P}_{\text {org }}$ & $\begin{array}{l}\text { Total P } \\
\text { (ICP- } \\
\text { OES) }\end{array}$ \\
\hline \multicolumn{7}{|l|}{ BY15 } \\
\hline & 0.25 & 896 & 9059 & & 19 & 52 \\
\hline & 0.75 & 959 & 9645 & & 18 & 52 \\
\hline & 1.25 & 752 & 7951 & & 16 & 45 \\
\hline & 1.75 & & & & 18 & 41 \\
\hline & 2.25 & 800 & 8244 & & 19 & 40 \\
\hline & 2.75 & 890 & 8862 & & 16 & 40 \\
\hline & 3.25 & 807 & 8425 & & 18 & 37 \\
\hline & 3.75 & 708 & 7129 & & & \\
\hline & 4.25 & 829 & 7821 & & 16 & 37 \\
\hline & 5 & 479 & 5004 & & 12 & 34 \\
\hline & 6 & 347 & 3751 & & 12 & 35 \\
\hline & 7 & 296 & 3229 & & 9 & 34 \\
\hline & 8 & 241 & 2760 & & 9 & 29 \\
\hline & 9 & 257 & 3117 & & 10 & 29 \\
\hline & 10.5 & 220 & 2771 & & 9 & 34 \\
\hline & 12.5 & 227 & 2763 & & 9 & 34 \\
\hline & 14.5 & 237 & 2789 & & 10 & 35 \\
\hline & 16.5 & 219 & 2595 & & & 31 \\
\hline & 18.5 & 233 & 2695 & & 9 & 33 \\
\hline & 20.5 & 254 & 2854 & & 9 & 33 \\
\hline & 22.5 & 252 & 2888 & & 10 & 32 \\
\hline & 24.5 & 232 & 2749 & & 9 & 33 \\
\hline & 26.5 & 220 & 2695 & & 8 & 27 \\
\hline & 29.5 & 252 & 2921 & & 9 & 30 \\
\hline & 33 & 300 & 3364 & & 10 & 30 \\
\hline & 35 & 316 & 3642 & & 10 & 30 \\
\hline & 36 & 315 & 3753 & & 10 & 32 \\
\hline & 37 & 323 & 3784 & & 10 & 34 \\
\hline & 38 & 346 & 3890 & & 10 & 40 \\
\hline & 39 & 314 & 3686 & & 9 & 38 \\
\hline
\end{tabular}


Table C1. Sediment solid phase parameters used in the calculation of ${ }^{210} \mathrm{~Pb}$-based age models.

\begin{tabular}{|c|c|c|c|c|c|c|c|c|c|c|}
\hline Core & $\begin{array}{l}\text { Sample } \\
\text { mid- } \\
\text { depth } \\
(\mathrm{cm})\end{array}$ & $\begin{array}{c}\text { Water } \\
\text { content } \\
\text { (wet } \\
\text { sed., \%) }\end{array}$ & $\begin{array}{c}\text { Salt } \\
\text { content } \\
\text { (wet } \\
\text { sed., } \\
\%)^{*}\end{array}$ & $\begin{array}{c}\text { Dry } \\
\text { bulk } \\
\text { density } \\
\text { (dry, } \\
\text { salt-free } \\
\text { sed., } \\
\mathrm{g} \mathrm{cm}^{-3} \text { ) }\end{array}$ & $\begin{array}{c}\text { Cumulative } \\
\text { mass at } \\
\text { base of } \\
\text { sample } \\
\left(\mathrm{g} \mathrm{cm}^{-2}\right)\end{array}$ & $\begin{array}{l}\text { Observed } \\
{ }^{210} \mathrm{~Pb} \\
\text { activity } \\
\text { (mBq }{ }^{-1}, \\
\text { salt corr.) }\end{array}$ & $\begin{array}{c}\text { Excess } \\
{ }^{210} \mathrm{~Pb} \\
\text { activity } \\
\left(\mathrm{mBqg}^{-1},\right. \\
\text { salt } \\
\text { corr. })^{* *}\end{array}$ & $\begin{array}{c}\text { Cumulative } \\
\text { excess } \\
{ }^{210} \mathrm{~Pb} \\
\text { activity } \\
\text { (mBq cm }{ }^{-2} \text {, } \\
\text { salt corr.) }\end{array}$ & $\begin{array}{c}\text { Year } \\
\text { (CRS } \\
\text { model) }\end{array}$ & $\begin{array}{c}\text { Mass } \\
\text { accumulation } \\
\text { rate } \\
\left(\mathrm{g} \mathrm{cm}^{-2} \mathrm{yr}^{-1},\right. \\
\text { CRS model })\end{array}$ \\
\hline \multicolumn{11}{|l|}{ LF1 } \\
\hline & 0.75 & 68.1 & 0.5 & 0.38 & 0.37 & 261.0 & 245.5 & 960.20 & 2008.2 & 0.125 \\
\hline & 1.25 & 65.8 & 0.5 & 0.42 & 0.58 & 250.4 & 234.9 & 913.01 & 2006.5 & 0.122 \\
\hline & 1.75 & 64.4 & 0.5 & 0.44 & 0.80 & 240.4 & 224.9 & 863.50 & 2004.8 & 0.120 \\
\hline & 2.5 & 63.6 & 0.5 & 0.46 & 1.26 & 222.5 & 207.0 & 813.49 & 2002.8 & 0.118 \\
\hline & 3.5 & 50.3 & 0.4 & 0.71 & 1.97 & 147.0 & 131.5 & 718.77 & 1998.9 & 0.130 \\
\hline & 8.5 & 62.4 & 0.5 & 0.48 & 5.26 & 151.4 & 135.9 & 243.59 & 1964.1 & 0.095 \\
\hline & 9.5 & 55.6 & 0.4 & 0.60 & 5.86 & 99.4 & 83.9 & 178.53 & 1954.1 & 0.089 \\
\hline & 11 & 55.2 & 0.4 & 0.61 & 7.08 & 89.9 & 74.4 & 128.05 & 1943.5 & 0.067 \\
\hline & 13 & 43.0 & 0.3 & 0.87 & 8.83 & 33.2 & 17.7 & 37.40 & 1903.9 & 0.055 \\
\hline & 15 & 40.9 & 0.3 & 0.92 & 10.67 & 16.0 & 0.5 & 6.49 & 1847.7 & 0.064 \\
\hline & 17 & 42.7 & 0.3 & 0.88 & 12.43 & 18.6 & & & & \\
\hline & 19 & 39.5 & 0.3 & 0.96 & 14.35 & 15.2 & & & & \\
\hline & 21 & 37.7 & 0.3 & 1.01 & 16.37 & 15.9 & & & & \\
\hline \multicolumn{11}{|l|}{ LF1.5 } \\
\hline & 0.25 & 85.7 & 0.7 & 0.14 & 0.07 & 439.2 & 423.2 & 1299.11 & 2009.5 & 0.094 \\
\hline & 0.75 & 84.2 & 0.7 & 0.16 & 0.15 & 474.2 & 458.2 & 1268.95 & 2008.7 & 0.089 \\
\hline & 7.5 & 56.0 & 0.5 & 0.59 & 2.95 & 159.1 & 143.1 & 670.73 & 1988.3 & 0.115 \\
\hline & 8.5 & 57.9 & 0.5 & 0.56 & 3.51 & 141.0 & 125.0 & 585.75 & 1983.9 & 0.118 \\
\hline & 9.5 & 56.0 & 0.5 & 0.59 & 4.10 & 124.5 & 108.5 & 515.96 & 1979.8 & 0.121 \\
\hline & 11 & 58.2 & 0.5 & 0.55 & 5.21 & 133.5 & 117.5 & 451.63 & 1975.6 & 0.116 \\
\hline & 13 & 63.9 & 0.5 & 0.45 & 6.11 & 163.8 & 147.8 & 321.93 & 1964.7 & 0.098 \\
\hline & 15 & 63.6 & 0.5 & 0.46 & 7.03 & 172.3 & 156.3 & 188.04 & 1947.4 & 0.065 \\
\hline & 17 & 42.0 & 0.3 & 0.90 & 8.82 & 39.4 & 23.4 & 45.08 & 1901.6 & 0.045 \\
\hline & 19 & 41.8 & 0.3 & 0.90 & 10.62 & 18.8 & 2.8 & 3.08 & 1815.4 & \\
\hline & 21 & 45.2 & 0.4 & 0.82 & 12.26 & 15.9 & & & & \\
\hline & 23 & 45.6 & 0.4 & 0.81 & 13.88 & 14.2 & & & & \\
\hline & 25 & 57.8 & 0.5 & 0.56 & 15.00 & 17.0 & & & & \\
\hline \multicolumn{11}{|l|}{ LF3 } \\
\hline & 0.25 & 92.4 & 0.9 & 0.06 & 0.03 & 817.4 & 789.4 & 1078.93 & 2009.5 & 0.042 \\
\hline & 0.75 & 92.1 & 0.9 & 0.07 & 0.06 & 744.0 & 716.0 & 1054.27 & 2008.8 & 0.044 \\
\hline & 1.25 & 90.5 & 0.9 & 0.08 & 0.11 & 643.1 & 615.1 & 1030.68 & 2008.0 & 0.046 \\
\hline & 1.75 & 87.1 & 0.9 & 0.12 & 0.17 & 499.6 & 471.6 & 1005.13 & 2007.2 & 0.052 \\
\hline & 2.5 & 85.4 & 0.9 & 0.14 & 0.31 & 442.6 & 414.6 & 976.23 & 2006.3 & 0.059 \\
\hline & 3.5 & 86.0 & 0.9 & 0.14 & 0.45 & 441.8 & 413.8 & 916.77 & 2004.3 & 0.061 \\
\hline & 4.5 & 84.3 & 0.9 & 0.16 & 0.60 & 415.5 & 387.5 & 860.58 & 2002.2 & 0.063 \\
\hline & 5.5 & 83.6 & 0.8 & 0.17 & 0.77 & 396.3 & 368.3 & 799.96 & 1999.9 & 0.063 \\
\hline & 6.5 & 82.5 & 0.8 & 0.18 & 0.95 & 389.4 & 361.4 & 739.12 & 1997.4 & 0.063 \\
\hline & 7.5 & 82.4 & 0.8 & 0.18 & 1.13 & 358.6 & 330.6 & 674.54 & 1994.4 & 0.062 \\
\hline
\end{tabular}

*Estimated from water content and bottom water salinity. **Assumed background (supported) ${ }^{210} \mathrm{~Pb}$ concentrations (mBq ${ }^{-1}$ ): LF1: 15.5, LF1.5: 16.0, LF3: 27.0 . 
Acknowledgements. This work was funded by grants from the Netherlands Organization for Scientific Research (Vidi grant to C. P. Slomp) and the EU BONUS project HYPoxia mitigation for Baltic Sea Ecosystem Restoration (HYPER). Crews and technicians onboard the HYPER/COMBINE cruise of May/June 2009 are acknowledged for their assistance, and Alf Norkko is thanked for provision of CTD data files. Laboratory assistance in Utrecht from Dineke van de Meent, Helen de Waard and Giovanni Dammers is also greatly appreciated, as is the practical and scientific assistance of Jos Gompelman, Eefje van Zadelhoff and Alissa Zuijdgeest.

Edited by: L. Cotrim da Cunha

\section{References}

Algeo, T. J. and Ingall, E.: Sedimentary C-org : P ratios, paleocean ventilation, and Phanerozoic atmospheric $p \mathrm{O}_{2}$, Palaeogeogr. Palaeocl., 256, 130-155, doi:10.1016/j.palaeo.2007.02.029, 2007.

Al-Hamdani, Z. and Reker, J.: Towards marine landscapes in the Baltic Sea, BALANCE interim report \#10, available at: http:// balance-eu.org/, 2007.

Boer, W., van den Bergh, G. D., de Haas, H., de Stigter, H. C., Gieles, R. and van Weering, T. C. E.: Validation of accumulation rates in Teluk Banten (Indonesia) from commonly applied Pb210 models, using the 1883 Krakatau tephra as time marker, Mar. Geol., 227, 263-277, 2006.

Boudreau, B. P.: Diagenetic models and their implementation, Springer, Germany, 1997.

Burdige, D. J.: Geochemistry of marine sediments, Princeton University Press, New Jersey, USA, 2006.

Cardinale, M. and Modin, J.: Changes in size-at-maturity of Baltic cod (Gadus morhua) during a period of large variations in stock size and environmental conditions, Fish. Res., 41, 285-295, 1999.

Conley, D. J., Bjorck, S., Bonsdorff, E., Carstensen, J., Destouni, G., Gustafsson, B. G., Hietanen, S., Kortekaas, M., Kuosa, H., Meier, H. E. M., Muller-Karulis, B., Nordberg, K., Norkko, A., Nurnberg, G., Pitkanen, H., Rabalais, N. N., Rosenberg, R., Savchuk, O. P., Slomp, C. P., Voss, M., Wulff, F. and Zillen, L.: Hypoxia-related processes in the Baltic Sea, Environ. Sci. Technol., 43, 3412-3420, doi:10.1021/es802762a, 2009a.

Conley, D. J., Bonsdorff, E., Carstensen, J., Destouni, G., Gustafsson, B. G., Hansson, L. A., Rabalais, N. N., Voss, M. and Zillen, L.: Tackling hypoxia in the Baltic Sea: Is engineering a solution?, Environ. Sci. Technol., 43, 3407-3411, doi:10.1021/es8027633, 2009b.

Conley, D. J., Humborg, C., Rahm, L., Savchuk, O. P. and Wulff, F.: Hypoxia in the Baltic Sea and basin-scale changes in phosphorus biogeochemistry, Environ. Sci. Technol., 36, 5315-5320, doi:10.1021/es025763w, 2002.

de Lange, G. J., Thomson, J., Reitz, A., Slomp, C. P., Principato, M. S., Erba, E. and Corselli, C.: Synchronous basin-wide formation and redox-controlled preservation of a Mediterranean sapropel, Nat. Geosci., 1, 606-610, doi:10.1038/ngeo283, 2008.

Diaz, R. J. and Rosenberg, R.: Marine benthic hypoxia: A review of its ecological effects and the behavioural responses of benthic macrofauna, Oceanogr. Mar. Biol., 33, 245-303, 1995.

Einsele, W.: Über die Beziehungen des Eisenkreislaufs zum Phosphorkreislauf im eutrophen See, Arch. Hydrobiol., 29, 664-686,
1936.

Emeis, K. C., Struck, U., Leipe, T., Pollehne, F., Kunzendorf, H., and Christiansen, C.: Changes in the $\mathrm{C}, \mathrm{N}, \mathrm{P}$ burial rates in some Baltic Sea sediments over the last 150 years - relevance to $\mathrm{P}$ regeneration rates and the phosphorus cycle, Mar. Geol., 167, 43-59, 2000.

Emeis, K. C., Christiansen, C., Edelvang, K., Jahmlich, S., Kozuch, J., Laima, M., Leipe, T., Loffler, A., Lund-Hansen, L. C., Miltner, A., Pazdro, K., Pempkowiak, J., Pollehne, F., Shimmield, T., Voss, M., and Witt, G.: Material transport from the near shore to the basinal environment in the southern Baltic Sea II: Synthesis of data on origin and properties of material, J. Mar. Syst., 35, 151-168, 2002.

Fonselius, S.: Oxygen and hydrogen-sulfide conditions in the Baltic Sea, Mar. Pollut. Bull., 12, 187-194, 1981.

Fonselius, S. and Valderrama, J.: One hundred years of hydrographic measurements in the Baltic Sea, J. Sea Res., 49, 229 241, 2003.

Gustafsson, B. G.: Time-dependent modeling of the Baltic entrance area. 2. Water and salt exchange of the Baltic Sea, Estuaries, 23, 253-266, 2000.

Gustafsson, B. G. and Stigebrandt, A.: Dynamics of nutrients and oxygen/hydrogen sulfide in the Baltic Sea deep water, J. Geophys. Res.-Bio., 112, G02023, doi:10.1029/2006JG000304, 2007.

Hille, S.: New aspects of sediment accumulation and reflux of nutrients in the Eastern Gotland Basin (Baltic Sea) and its impact on nutrient cycling, Ph.D. thesis, Inst. of Biol., Rostock Univ., Rostock, Germany, 2005.

Hille, S., Nausch, G., and Leipe, T.: Sedimentary deposition and reflux of phosphorus $(\mathrm{P})$ in the Eastern Gotland Basin and their coupling with $\mathrm{P}$ concentrations in the water column, Oceanologia, 47, 663-679, 2005.

Ingall, E. and Jahnke, R.: Influence of water-column anoxia on the elemental fractionation of carbon and phosphorus during sediment diagenesis, Mar. Geol., 139, 219-229, 1997.

Ingall, E. D., Bustin, R. M., and Van Cappellen, P.: Influence of water column anoxia on the burial and preservation of carbon and phosphorus in marine shales, Geochim. Cosmochim. Ac., 57, 303-316, 1993.

Intergovernmental Oceanographic Commission, International Hydrographic Organization and British Oceanographic Data Centre: Centenary Edition of the GEBCO Digital Atlas, published on CD-ROM on behalf of the Intergovernmental Oceanographic Commission and the International Hydrographic Organization as part of the General Bathymetric Chart of the Oceans, British Oceanographic Data Centre, Liverpool, U.K., 2003.

Janssen, F., Neumann, T., and Schmidt, M.: Inter-annual variability in cyanobacteria blooms in the Baltic Sea controlled by wintertime hydrographic conditions, Mar. Ecol.-Prog. Ser., 275, 59-68, 2004.

Jonsson, P., Carman, R., and Wulff, F.: Laminated sediments in the Baltic: A tool for evaluating nutrient mass balances, Ambio, 19, 152-158, 1990.

Karlson, K., Hulth, S., Ringdahl, K., and Rosenberg, R.: Experimental recolonisation of Baltic Sea reduced sediments: survival of benthic macrofauna and effects on nutrient cycling, Mar. Ecol.-Prog. Ser., 294, 35-49, 2005.

Kemp, W. M., Sampou, P., Caffrey, J., Mayer, M., Henriksen, K., 
and Boynton, W. R.: Ammonium recycling versus denitrification in Chesapeake Bay sediments, Limnol. Oceanogr., 35, 15451563, 1990.

Kraal, P., Slomp, C. P., and de Lange, G. J.: Sedimentary organic carbon to phosphorus ratios as a redox proxy in Quaternary records from the Mediterranean, Chem. Geol., 277, 167177, doi:10.1016/j.chemgeo.2010.08.003, 2010.

Kraal, P., Slomp, C. P., Forster, A., Kuypers, M. M. M., and Sluijs, A.: Pyrite oxidation during sample storage determines phosphorus fractionation in carbonate-poor anoxic sediments, Geochim. Cosmochim. Ac., 73, 3277-3290, doi:10.1016/j.gca.2009.02.026, 2009.

Lass, H. U. and Matthaus, W.: On temporal wind variations forcing salt water inflows into the Baltic Sea, Tellus A, 48, 663-671, 1996.

Lilover, M. and Stips, A.: The variability of parameters controlling the cyanobacteria bloom biomass in the Baltic Sea, J. Mar. Syst., 74, S108-S115, doi:10.1016/j.jmarsys.2008.03.029, 2008.

Lukkari, K., Leivuori, M., and Kotilainen, A.: The chemical character and behaviour of phosphorus in poorly oxygenated sediments from open sea to organic-rich inner bay in the Baltic Sea, Biogeochemistry, 96, 25-48, doi:10.1007/s10533-009-9343-7, 2009.

Matthaus, W. and Franck, H.: Characteristics of major Baltic inflows - a statistical-analysis, Cont. Shelf Res., 12, 1375-1400, 1992.

Meier, H. E. M., Feistel, R., Piechura, J., Arneborg, L., Burchard, H., Fiekas, V., Golenko, N., Kuzmina, N., Mohrholz, V., Nohr, C., Paka, V. T., Sellschopp, J., Stips, A., and Zhurbas, V.: Ventilation of the Baltic Sea deep water: A brief review of present knowledge from observations and models, Oceanologia, 48, 133-164, 2006.

Middelburg, J. J. and Levin, L. A.: Coastal hypoxia and sediment biogeochemistry, Biogeosciences, 6, 1273-1293, doi:10.5194/bg-6-1273-2009, 2009.

Mort, H. P., Slomp, C. P., Gustafsson, B. G., and Andersen, T. J.: Phosphorus recycling and burial in Baltic Sea sediments with contrasting redox conditions, Geochim. Cosmochim. Ac., 74, 1350-1362, doi:10.1016/j.gca.2009.11.016, 2010.

Mortimer, C. H.: The exchange of dissolved substances between mud and water in lakes, J. Ecol., 29, 280-329, 1941.

Mortimer, C. H.: The exchange of dissolved substances between mud and water in lakes, J. Ecol., 30, 147-201, 1942.

Nausch, M., Nausch, G., Lass, H. U., Mohrholz, V., Nagel, K., Siegel, H., and Wasmund, N.: Phosphorus input by upwelling in the eastern Gotland Basin (Baltic Sea) in summer and its effects on filamentous cyanobacteria, Estuar. Coast. Shelf S., 83, 434442, 2009.

Reed, D. C., Slomp, C. P., and Gustafsson, B. G.: Sedimentary phosphorus dynamics and the evolution of bottom water hypoxia: a coupled benthic-pelagic model of a coastal system, Limnol. Oceanogr., in press., 2011.

Ruttenberg, K. C.: Development of a sequential extraction method for different forms of phosphorus in marine sediments, Limnol. Oceanogr., 37, 1460-1482, 1992.

Savchuk, O. P., Wulff, F., Hille, S., Humborg, C., and Pollehne, F.: The Baltic Sea a century ago - a reconstruction from model simulations, verified by observations, J. Mar. Syst., 74, 485-494, doi:10.1016/j.jmarsys.2008.03.008, 2008.

Savchuk, O. P. and Wulff, F.: Long-term modeling of large-scale nutrient cycles in the entire Baltic Sea, Hydrobiologia, 629, 209224, doi:10.1007/s10750-009-9775-z, 2009.

Schenau, S. J. and de Lange, G. J.: Phosphorus regeneration vs. burial in sediments of the Arabian Sea, Mar. Chem., 75, 201217, 2001.

Schinke, H. and Matthaus, W.: On the causes of major Baltic inflows - an analysis of long time series, Cont. Shelf Res., 18, 6797, 1998.

Seeberg-Elverfeldt, J., Schluter, M., Feseker, T., and Kolling, M.: Rhizon sampling of porewaters near the sediment-water interface of aquatic systems, Limnol. Oceanogr.-Meth., 3, 361-371, 2005.

Slomp, C. P., Epping, E. H. G., Helder, W., and Van Raaphorst, W.: A key role for iron-bound phosphorus in authigenic apatite formation in North Atlantic continental platform sediments, J. Mar. Res., 54, 1179-1205, 1996.

Slomp, C. P., Malschaert, J. F. P., and Van Raaphorst, W.: The role of adsorption in sediment-water exchange of phosphate in North Sea continental margin sediments, Limnol. Oceanogr., 43, 832846, 1998.

Slomp, C. P., Thomson, J., and de Lange, G. J.: Enhanced regeneration of phosphorus during formation of the most recent eastern Mediterranean sapropel (S1), Geochim. Cosmochim. Ac., 66, 1171-1184, 2002.

Stigebrandt, A.: Computations of oxygen fluxes through the seasurface and the net production of organic-matter with application to the Baltic and adjacent seas, Limnol. Oceanogr., 36, 444-454, 1991.

Strickland, J. D. and Parsons, T. R.: A practical handbook of seawater analysis, Bulletin 167, Fisheries Research Board of Canada, Ottawa, Canada, 1972.

Struck, U., Pollehne, F., Bauerfeind, E. and Bodungen, B. V.: Sources of nitrogen for the vertical particle flux in the Gotland Sea (Baltic Proper) - results from sediment trap studies, J. Mar. Syst., 45, 91-101, doi:10.1016/j.jmarsys.2003.11.012, 2004.

Turnewitsch, R. and Pohl, C.: An estimate of the efficiency of the iron- and manganese-driven dissolved inorganic phosphorus trap at an oxic/euxinic water-column redoxcline, Global Biogeochem. Cy., 24, GB4025, doi:10.1029/2010GB003820, 2010.

Vahtera, E., Conley, D. J., Gustafsson, B. G., Kuosa, H., Pitkanen, H., Savchuk, O. P., Tamminen, T., Viitasalo, M., Voss, M., Wasmund, N., and Wulff, F.: Internal ecosystem feedbacks enhance nitrogen-fixing cyanobacteria blooms and complicate management in the Baltic Sea, Ambio, 36, 186-194, 2007.

Van Cappellen, P. and Ingall, E. D.: Response to comment "Redox stabilization of the atmosphere and oceans and marine productivity" edited by: Colman, A. S., Mackenzie, F. T., and Holland, H. D., Science, 275, 407-408, 1997.

Van Cappellen, P. and Wang, Y.: Metal cycling in sediments: Modeling the interplay of reaction and transport, in: Metal contaminated aquatic sediments, edited by: Allen, H. E., Ann Arbor Press, Michigan, USA, 1995.

Van Santvoort, P. J. M., De Lange, G. J., Thomson, J., Colley, S., Meysman, F. J. R., and Slomp, C. P.: Oxidation and origin of organic matter in surficial eastern Mediterranean hemipelagic sediments, Aquat. Geochem., 8, 153-175, 2002.

Zillén, L., Conley, D. J., Andrén, T., Andrén, E., and Björck, S.: Past occurrences of hypoxia in the Baltic Sea and the role of climate variability, environmental change and human impact, Earth Sci. Rev., 91, 77-92, 2008. 